\title{
Conversación en París con André Vauchez*
}

\author{
Umberto LONGO** / Gian Maria VARANINI ${ }^{* * *}$ \\ ** Università di Roma La Sapienza \\ umberto.longo@uniroma1.it \\ **** Università degli Studi di Verona \\ gianmaria.varanini@univr.it
}

\section{LOS AÑOS DE FORMACIÓN ENTRE ESTRASBURGO Y PARÍS}

Pregunta. Nos gustaría empezar preguntándole por sus primeros años de vida y por su vivencia de la Segunda Guerra Mundial.

Respuesta. Nacido en 1938 en el seno de una familia originaria del Franco Condado -región situada entre la Borgoña y Suiza-, viví en Paris durante la Segunda Guerra Mundial aunque solo conservo recuerdos posteriores al verano de 1944: mientras pasábamos las vacaciones de verano en casa de mi abuela materna, no lejos de Besanzón, la armada alemana, que se batía en retirada desde las orillas del Mediterráneo, atravesó la ciudad durante varios días hostigada por la Resistencia. En esa ocasión, tuve mi primera experiencia con la muerte (un oficial alemán fusilado por los partisanos a dos pasos de nuestra casa), y descubrí poco más tarde la existencia del chicle (chewing-gum) cuando un simpático soldado americano me ofreció un paquete. Después de estos sucesos, que podrían haber sido más trágicos aún, mi padre que era funcionario de aduanas fue transferido a Estrasburgo donde viví sin interrupción desde 1945 hasta 1958, y donde hice mis estudios, desde la escuela primaria hasta la universidad. Al principio, la ciudad era de lengua alemana -incomprensible para mí- pero con el paso del tiempo el uso del francés se acabó imponiendo ampliamente. Esta situación de bilingüismo no hizo de mí un gran

* Esta entrevista fue publicada (en su versión completa) en francés e italiano en la revista Reti Medievali Rivista, 15/1 (2014). Agradecemos al Comité Editorial de la revista así como a los autores de la entrevista el permiso para publicarla en español. La traducción ha corrido a cargo de la redacción de la revista. Se ha completado alguna nota al pie haciendo referencia a las ediciones españolas de las obras citadas. 
«germanista» (de hecho, no aprendí el alemán en la escuela y aún ahora no soy capaz de hablarlo correctamente), pero me permitió descubrir, una vez borrados los tristes recuerdos de la guerra, la riqueza cultural y artística del mundo renano que fue una de las cunas de la civilización medieval, como lo atestigua aún hoy día la catedral de Estrasburgo y el claustro de Unterlinden en Colmar.

P. Durante los años de la escuela, ¿ cómo surge su interés por la Edad Media?

R. Me eduqué en un liceo público (aun siendo católico, nunca fui a una escuela privada) dedicado a Fustel de Coulanges, el gran especialista de la Antigüedad, de finales del XIX. Como esta escuela se encontraba al lado de la catedral, me pasaba horas, los días de buen tiempo, mirando como el sol iluminaba los bloques de gres rosado de su famosa flecha. No sabría decir si este espectáculo cotidiano está en el origen de mi vocación de historiador, pero es posible que haya contribuido de manera inconsciente a ella; en todo caso, fue estimulada por la lectura de un libro titulado L'Eglise de la cathédrale et de la croisade, obra del historiador católico Daniel-Rops ${ }^{1}$, que recibí como premio cuando tenía trece o catorce años.

P. A propósito de Estrasburgo, lugar de su formación en los años cincuenta, usted ba bablado en repetidas ocasiones de «el clima europeo», en el sentido de la presencia de un pluralismo lingüistico y cultural que ha contribuido a formar en usted una «convicción europea», desarrollada después grandemente ${ }^{2}$. ¿Podría ilustrarnos sobre este «clima» particular? Qué relación tiene este clima con aquella «laicidad abierta» a la que usted se refiere con frecuencia?

R. Estos años de liceo fueron importantes para mí, pues me permitieron entrar en contacto con la diversidad religiosa. En Alsacia-Lorena, en efecto, el concordato firmado en 1801 entre la Iglesia y el Estado está aún en vigor y prevé que exista una enseñanza religiosa dentro del programa de estudios escolar: en mi clase, donde había muchos protestantes y judíos, nos separábamos en el momento de la asignatura de religión para seguir las clases dadas por un sacerdote, por un pastor o por un rabino, mientras que los pocos «no creyentes» se iban a hacer sus deberes a otra aula. Está experiencia de laicidad abierta en la cual el Estado, a la vez que conservaba su neutralidad confesional frente a las diversas confesiones, respetando la libertad de conciencia, garantizaba no solo el

1 Daniel-Rops (Henri Petiot), L'Église de la cathédrale et de la croisade, Paris, 1952 (Historie de l'Église du Christ, III). En español, Historia de la Iglesia de Cristo, 4. La catedral y la cruzada (Primera parte); 5. La catedral y la cruzada (Segunda parte), Caralt, Barcelona, 1978.

2 Dominique Rigaux y Daniel RUSSO-Catherine VINCENT (eds.), Expériences religieuses et chemins de perfection dans l'Occident médiéval, études offertes à André Vauchez par ses élèves, Paris, 2012, p. 35 . 
libre ejercicio del culto sino también la expresión pública de la propia fe, me ha marcado profundamente. De esta manera, en una ciudad donde la presencia de diversas confesiones estaba reconocida incluso en el terreno cultural, yo descubrí el pluralismo religioso y aprendí, desde temprana edad, a respetar las creencias y los comportamientos de los otros. En la escuela, mis compañeros judíos no escribían los sábados -nosotros les tomábamos los apuntes- y me hablaban con entusiasmo del Estado de Israel que acababa de nacer, mientras que yo trataba de comprender -no lo conseguí hasta más tarde- que es lo que separaba a católicos de protestantes pues me parecían muy próximos.

En mis últimos años escolares, se me hizo evidente y también a mis padres que la historia era la materia que más me gustaba y en la que obtenía mejores resultados, mientras que no brillaba especialmente en las asignaturas científicas. Mi padre era un apasionado de la historia y, si la Primera Guerra Mundial no hubiera interrumpido prematuramente su escolaridad, él hubiera continuado, sin lugar a dudas, sus estudios en este campo. Sin saberlo, yo iba a realizar su sueño y creo que le hice feliz. Después del bachillerato, permanecí en el mismo liceo de Estrasburgo (1955-1957) preparando el concurso para la entrada en la Escuela Normal Superior, a la vez que frecuentaba algunos cursos en la universidad. Tuve entonces la ocasión de codearme con dos grandes filósofos, Paul Ricoeur y Julien Freund, que traducían al francés las obras de Max Weber y de Carl Schmitt; sin embargo yo nunca he tenido una cabeza filosófica y no sabría decir si sus enseñanzas han dejado en mí alguna influencia. Sin embargo, hice grandes progresos en latín y griego y quedé conquistado por mi profesor de francés, Jean Baudry, que me reveló un mundo desconocido, de Pascal a Stendhal y Baudelaire, lo que me llevó a devorar en pocos años lo esencial de la literatura antigua y reciente. Por otra parte, el capellán de los estudiantes de letras de Estrasburgo, el padre Pierre Bockel, me descubrió la obra de Bernanos y sobre todo de Malraux, con el cual estaba personalmente muy ligado, por haber combatido con él contra el nazismo en 1944-1945 dentro de la brigada «Alsacia-Lorena». Habiendo fracasado en mi primer intento de ingresar en la Escuela Normal, tomé la decisión de marchar a Paris donde la preparación era más intensa y, después de un año de trabajo tenaz, fui finalmente admitido en julio de 1958.

P. Hablemos ahora de la formación universitaria, en la Escuela Normal Superior (1958-1963). Con ocasión del Coloquio de 2009 titulado Chemins de perfection, expériences religieuses dans l'Occident médiéval, cuando citaba a sus maestros de la calle Ulm (Escuela Normal Superior), mencionó a Michel Mollat, Facques Le Goff, Henri-Irénée Marrou, Gabriel Le Bras, Michelde Certeau, Alphonse Dupront: a quienes encontró precisamente durante sus años universitario vividos en la calle Ulm. ¿Cómo 
estas diferentes influencias se armonizan o contraponen con sus reflexiones de esos años parisinos?

R. Desde mi llegada a la Escuela Normal, mostré mi intención de especializarme en historia, pero aún no había escogido el período al que me quería dedicar en particular. Mi vocación de medievalista no era para mí algo evidente. Yo había estudiado muchísimo la antigüedad y estaba interesado por aquel entonces en la arqueología. Pero una estancia que hice en unas excavaciones arqueológicas en Provenza en 1959 me convenció rápidamente de que la realidad vivida sobre el terreno estaba muy alejada de lo que había imaginado y que no poseía ni la habilidad manual ni la paciencia necesaria para dedicarme a este campo. A partir del año siguiente, varios encuentros personales me persuadieron para que orientara mis esfuerzos hacia la historia religiosa. Entre 1960 y 1962, tuve la fortuna de poder seguir los cursos de grandes maestros en la Sorbona y en la École pratique des Hautes Études y quedé impactado por la calidad de sus enseñanzas. Los más importantes fueron Henri-Irénée Marrou, Michel Mollat y Jacques Le Goff en Paris y, en Estrasburgo donde volvía con frecuencia para ver a mi novia y donde hice el servicio militar (1963-1965), el padre Congar que se encontraba por aquel entonces en el convento de los dominicos, después de haber pasado un «exilio» en Inglaterra hacía el final del pontificado de Pío XII, por decisión del Santo Oficio.

Cada una de estas personalidades tenía sus características particulares: Marrou, bajo cuya dirección escribí una memoria titulada «Les premiers chrétiens et la guerre», tenía un dominio exquisito de las fuentes patrísticas y daba la impresión de conocer de memoria la obra de san Agustín... Apreciaba de él sobre todo su buen humor que le permitía tratar cuestiones muy serias y complejas sin que sus oyentes se aburrieran y, de hecho, guardo un recuerdo inolvidable de su seminario sobre las herejías en el seno del cristianismo en los siglos III y IV.

Pero ya me había alejado de la Antigüedad y la Edad Media me parecía un campo más nuevo y atrayente. Michel Mollat era un hombre muy abierto y de una extrema cortesía. El impartía un curso sobre «Les villes au Moyen Âge» que me parecía muy interesante, pero también era muy competente en historia económica, social y religiosa. Desde mi punto de vista, era un historiado completo, que se encontraba a gusto en todos los campos y esta impresión se reforzó cuando empecé a seguir su seminario de investigación sobre «Les pauvres et la pauvreté au Moyen Âge». Honestamente, no sabría decir, a día de hoy, si fue él quien me persuadió para que trabajara en la santidad medieval, o si esta idea-que a algunos les parecía un poco loca- me vino después de una conversación con Charles de La Roncière, por aquel entonces ayudante en la Sorbona. De todos modos, Mollat 
aceptó este tema e hice bajo su dirección una memoria de doctorado sobre «La sainteté en Occident au Moyen Âge». Complacido con mi trabajo, me gané hasta tal punto su confianza que me envió a Todi en 1967 para que presentara en su lugar una comunicación sobre «Les pauvres et la pauvreté en Occident aux $\mathrm{XI}^{\mathrm{e}}$ et $\mathrm{XII}^{\mathrm{e}}$ siècles», con ocasión del VIII Congreso del «Centro di studi sulla spiritualità medievale»³.

P. De los estudiosos citados con anterioridad solo respecto a uno de ellos se ha referido como un «choque intelectual», haciendo mención al curso dado por Facques Le Goff sobre el trabajo en la Edad Media, en la École de la calle Ulm. ¿Podría hablarnos de ello?

R. Volviendo a los inicios de los 60, los trabajos y la personalidad de Jacques Le Goff, cuyos cursos seguía, me dejaron una profunda marca; me acuerdo de modo particular del magnífico curso que hizo en la Escuela Normal Superior sobre «Le travail au Moyen Âge» en 1961-1962 y, después de conseguir mi titularidad en Historia en julio de 1962, su seminario de tercer ciclo de 1962-1963 sobre las herejías medievales que se impartía en una sala oscura y siempre repleta de la calle de Feuillantines. A través de su magisterio descubrí la escuela de los «Annales», entonces en plena expansión, así como la importancia que podía tener para la historia de la Edad Media el recurso a la etnología.

P. En el coloquio de diciembre de 2009 organizado en su honor, Daniel Russo presentó una relación bistoriográfica titulada André Vauchez lector de Alphonse Dupront. Usted comentó estar relación diciendo que le habia fascinado inicialmente más el personaje que su discurso; a continuación, a través de la lectura de Du Sacré, usted ha llegado a comprender mejor y a intuir «la dimensión histórica de la mentalidad religiosa (peregrinaciones, santuarios, cruzadas, religión popular, escatología), cosas a las que pocos se interesaban por aquel entonces en Francia». ¿En qué época sucedió esto? ¿Siendo estudiante en la calle Ulm?

R. Sí, yo seguía las clases de Alphonse Dupront, un maestro impresionante pero muy distante, que me inició en la antropología religiosa de Europa y me hizo comprender el papel importante jugado por el inconsciente en los grandes traumas colectivos, como las cruzadas y lo que él llamaba las «peregrinaciones del pánico». No obstante, debo reconocer, en honor a la verdad, que fui más influido por la lectura de sus libros que por su enseñanza oral en la que utilizaba un lenguaje oscuro e incluso esotérico, de tal manera que -cosa rara- ¡hablaba como escribía!... Siempre en 1962-1963 seguí el seminario de Gabriel Le Bras,

3 Les pauvres et la pauvreté aux XI et XII siècles. État des recherches en France, in Povertà e richezza nella spiritualità dei secoli XI e XII (Todi, 1967), Todi, 1969, pp. 227-244, reproducido en André VAUCHEZ, Religion et société dans l'Occident médiéval, Turin, 1980, pp. 3-18. 
una personalidad fascinante que me mostró la utilidad de una aproximación sociológica a los hechos religiosos y la importancia del derecho canónico en la vida de la Iglesia occidental.

P. Ha becho alusión a su encuentro con Yves-Marie Congar en Estrasburgo, un personaje a que ba jugado un papel significativo en su vida y que participó en el Concilio Vaticano II; en los años noventa, usted ha querido rendirle homenaje editando un volumen en su honor, y señalando los frecuentes contactos, también personales, que ha tenido con él. ¿De qué modo un joven católico francés, en los años cincuenta, consigue entrar en contacto con el pensamiento de estos teólogos que más tarde renovarían la eclesiología?

R. Efectivamente, la orientación de mis trabajos fue influida por los trabajos de Yves Congar sobre la historia de la Iglesia y por las discusiones que tuve con él, en particular cuando, a finales de agosto de 1965, le llevé en coche desde Estrasburgo hasta el Passo de la Mendola, en las Dolomitas, donde la Universidad Católica de Milán organizaba unas «semanas» consagradas a diversos aspectos de la vida religiosa de la Edad Media. Allí, dio una espléndida conferencia sobre «Les laïcs dans la société chrétienne des $\mathrm{XI}^{\mathrm{e}}$ et $\mathrm{XII}^{\mathrm{e}}$ siècles», que reforzó mi convicción de que el papel y la espiritualidad de los laicos habían sido infravalorados por la historiografía católica y me incitó, más tarde, a desarrollar investigaciones sobre las cofradías, los peregrinos y los movimientos religiosos populares. A pesar de que Juan Pablo II le hizo cardenal un poco antes de su fallecimiento, me parece que la Iglesia no ha percibido suficientemente la importancia de la obra histórica de Congar, que no ha sido menor que la teológica. Así, organicé en la École Française de Rome, en 1996 -un año después de su muerte- un coloquio en su honor en el que algunos de los más grandes historiadores italianos -Giuseppe Alberigo, Ovidio Capitani, Girolamo Arnaldi- así como franceses y belgas le rindieron un homenaje bien merecido ${ }^{4}$. Pero también le debo al padre Congar haber superado rápidamente la «espontaneidad» de los años 1968 y haber descubierto la importancia de la eclesiología, es decir, la consciencia que cada Iglesia o comunidad religiosa tiene de sí misma y de su papel en la perspectiva de la salvación. Largo tiempo hostil, por principio, a las instituciones eclesiásticas, pude, gracias a él y a Gabriel Le Bras, comprender mejor su función: si ellas han obstaculizado frecuentemente la renovación de la Iglesia por su lentitud o por su conservadurismo, también la han favorecido en momentos decisivos, como en los inicios del siglo XIII o en el pontificado de Juan XXIII que hizo posible el Vaticano II. Aún más, hay que admitir que en muchas ocasiones, han evitado que

4 André VAuCHEZ (ed.), Cardinal Ives Congar (1904-1995), Paris, 1999. 
iniciativas espirituales que querían reformar la Iglesia no provocaran una mayor confusión suscitando desasosiego y tensiones fuertes entre los fieles.

A este respecto, uno se maravillaría de la influencia considerable que han tenido ciertos religiosos -sobre todo dominicos y jesuitas- en los medios universitarios franceses, más bien conocidos por su anticlericalismo, en el último tercio del siglo XX. En efecto, mi caso dista de ser el único e incluso un historiador alejado de todo credo como Jacques Le Goff ha reconocido públicamente todo lo que le debía a Marie-Dominique Chenu en el elogio que hizo de este último, con ocasión de sus exequias en Notre-Dame de París. Algo parecido se puede decir, mutatis mutandis, a propósito de Louis-Jacques Bataillon OP, que se ha ganado por su competencia científica y su generosidad la simpatía y la admiración de los que trabajan en el campo de la predicación medieval en el mundo entero, o aún de algunos de los grandes jesuitas como Henri de Lubac o Michel de Certeau. El hecho es aún más llamativo porque esta generación de religiosos, que fueron a la vez grandes historiadores, ha desaparecido. Hoy día los clérigos han desertado del estudio de la historia que, para algunos, es simplemente una ancilla theologiae, mientras que para Chenu y Congar era la teología la que debía reconocer que sus formulaciones estaban ligadas a los contextos históricos y que sus enunciados no constituían la expresión inmutable de una doctrina que sería extraña a las vicisitudes de la sociedad y de la cultura ambiental.

P. Es dentro de este itinerario que le ha llevado al interés por lo «sagrado», en el sentido más amplio del término, que se sitúa su trabajo en el seno del grupo interdisciplinar de historia religiosa de la Bussière, es decir, el grupo que «agrupa a los historiadores de la Antigüedad hasta el período contemporáneo a través de encuentros anuales tan simpáticos como constructivos». 5 .

R. Llegado a este punto, debo, para ceñirme al relato cronológico, mencionar el papel que ha jugado en mi formación de historiador el «Groupe de la Bussière» que empecé a frecuentar en sus reuniones estivales a partir de 1961 y que aún existe, aunque ya sin jugar el papel que tuvo en sus inicios para la historiografía francesa. Se trata de un grupo informal, creado a finales de 1950 por algunos jóvenes investigadores en historia religiosa (Charles de la Roncière, Jean Chelini, Marc Venard, etc.), que debe su nombre al hecho de que durante bastantes años, desde sus inicios, ha tenido sus sesiones en la antigua abadía de La Bussière, en Borgoña, convertida en casa de retiro y reposo. La originalidad de este grupo, cuando entré en él, era que acogía a los historiadores que trabajaban

5 Cfr. Expériences religieuses et chemins de perfection, p. 41. 
sobre todos los periodos de la historia del cristianismo, desde la antigüedad hasta la historia contemporánea, y que no tenía cuenta de las jerarquías académicas ni de las pertenencias confesionales o ideológicas. Un joven investigador debutante, como era mi caso en los sesenta, se encontraba en igualdad de condiciones con un profesor ya ilustre y podía discutir con él. En los comienzos, se invitaba a una «vedette» prestigiosa para que diera dos o tres lecciones sobre el tema del encuentro, que duraba cuatro o cinco días. De esta manera, tuve la oportunidad de conocer, en un ambiente de gran distensión, personalidades de primer rango como Jean Hadot, especialista de la apocalíptica judía y cristiana, Étienne Delaruelle que fue uno de los primeros en Francia en interesarse en la piedad de los laicos en la Edad Media, o también Jean Delumeau y Michel de Certeau que rápidamente se convirtió en uno de los principales animadores del grupo. El tema del encuentro cambiaba cada año y todos los que pensaban que podían decir algo sobre el tema podían intervenir libremente ya sea presentando una exposición o participando simplemente en la discusión. Pero este encuentro anual no era un congreso; por regla general, no se publicaban las actas (la única excepción fue el volumen sobre $\ll$ La confession ${ }^{6}$ ) y cada comunicación era discutida no solo por los especialistas del periodo considerado sino por todos los miembros del grupo. Yo fui introducido por Charles de La Ronciére, que trabajaba sobre la Toscana medieval, y por mi cuñado Jean-Marie Mayeur (1933-2013) que hacía en esos momentos una tesis sobre la Democracia cristiana en Francia desde finales del siglo XIX.

El grupo de la Boussière había surgido de la toma de conciencia de una parte de la nueva generación de investigadores sobre la situación poco satisfactoria de la historia religiosa en Francia. En los medios eclesiásticos predominaba aún, con demasiada frecuencia, una concepción puramente institucional de la historia, que privilegiaba como temas de estudio el papel de la jerarquía y de las órdenes religiosas concediendo poca atención a los laicos y a las conexiones que existían en una u otra época entre la «vivencia» religiosa de los cristianos y el medio social y cultural al que pertenecían. En la enseñanza superior pública, la historia religiosa ocupaba un lugar reducido en razón de su carácter muy tradicional y de las tendencias apologéticas de muchos de sus enseñantes. De esta manera, un estudiante de historia medieval en la Sorbona, como era yo entonces, podía llegar al final de su carrera universitaria sin haber oído nunca hablar de la vida religiosa, fuera de las nociones generales sobre los conflictos entre ¡el papado y el imperio y las cruzadas!

6 Pratiques de la confession. Des Pères du désert à Vatican II, éd. Groupe de la Bussière, Paris, 1983. 
P. ¿De qué manera «el grupo de La Bussière» ha puesto en marcha el proyecto de una Historie du christianisme? ¿En qué aspecto este proyecto es innovador en relación a la bistoria tradicional, apologética, de las instituciones eclesiásticas, y en particular a la luz de las sugerencias provenientes del clima conciliar?

R. Del malestar que sentíamos en aquella época frente a la situación historiográfica tan decepcionante es testimonio un artículo que escribí junto con tres colegas de la calle Ulm (Dominique Julia, Philippe Levillain, Daniel Nordman) titulado «Réflexions sur l'historiographie française contemporaine» publicado por el Centre Catholique des intellectuels français ${ }^{7}$. Cuando lo releí no estaba orgulloso de él y lo encontraba injusto con algunos autores tales como HenriIrenée Marrou y Étienne Delaruelle, que habían contribuido con sus trabajos a relanzar la historia religiosa en Francia sobre bases nuevas. Pero este libelo, aun siendo excesivo, tenía la virtud de poner en evidencia la debilidad de una «historia neo-güelfa, triunfalista y cimera» (es decir, que privilegiaba la cúspide de la Iglesia en detrimento de la base) y subrayar las carencias de la historiografía francesa en este parcela. Escribía a este propósito (p. 94):

Queda aún por introducir el progreso que se ha dado en la historia profana para superar la ruptura entre la «historia-batalla» y la verdadera vida de los pueblos... Para que una auténtica historia de la Iglesia sea posible, habría que revisar sus centros de interés -es decir, estudiar primordialmente las manifestaciones de la piedad, de la liturgia y de la santidad- y sus métodos, es decir, no dudar en acudir a la psicología, a la iconografía y sobre todo a la sociología porque la Iglesia es ante todo pueblo y sociedad.

Hoy en día, un «manifiesto» de este tipo puede parecer banal o naif, pero no lo era cuando fue escrito y su publicación me provocó no pocas molestias en los inicios de mi carrera universitaria puesto que había herido ciertas susceptibilidades... Veinte años más tarde, hojeando por casualidad un libro dedicado a las personalidades cuya acción reformadora habían hecho posible el éxito del Concilio Vaticano II, quedé sorprendido por encontrar entre ellos mi nombre y el de los coautores del artículo. Según el autor del libro, el artículo habría marcado un cambio de ruta dentro de la historiografía religiosa y ¡la entrada de esta en una nueva era! El elogió me parecía excesivo, pero no es falso afirmar que nuestro

7 Dominique Julia, Philippe LeVIllain, Daniel Nordman y André Vauchez, Réflexions sur l'historiographie française contemporaine, en L'bistoire et l'historien, Recherches et débats du Centre catholique des intellectuels français, 47 (1964), pp. 79-94. 
panfleto reflejaba a la vez la decepción de mi generación de historiadores con la situación heredada y nuestras esperanzas en el futuro.

Uno de los objetivos del grupo de La Bussière fue, en efecto, introducir en el campo de la historia religiosa las exigencias críticas que ya prevalecían en las otras disciplinas históricas y abrirla a las ciencias sociales, en particular a la sociología y a la antropología. Nosotros no éramos ni un grupo de presión ni un «lobby» influyente, pero sí que es cierto que entre 1960 y 1990, numerosos trabajos escritos por los miembros de este grupo han contribuido a cambiar la fisonomía de la historia religiosa en Francia llevándola a un alto nivel científico, hasta el punto de que algunas de sus realización se convirtieron en modélicas, o al menos en referencia obligada para los investigadores de otros países de Europa y América.

Fue dentro de esta corriente, que trascendía las periodizaciones clásicas de la historia y las compartimentaciones consecuentes, que nació a finales de los años ochenta la idea de realizar una nueva Historia de la Iglesia. En el ínterin, un cierto número de jóvenes investigadores, perteneciente a este grupo desde los años sesenta, se habían convertido ya en profesores universitarios, dotados de un centro de investigación, y directores de sus propias tesis de doctorado, lo cual les hizo salir de su marginalidad inicial. Todos compartíamos en mayor o menor medida la misma insatisfacción frente a la vieja «Historia de la Iglesia» dirigida por Augustin Fliche y Victor Martin que había surgido en los años treinta del siglo XX y cuyos últimos volúmenes se habían publicado en 1963. Existían numerosas lagunas en esa colección y la empresa parecía estar en vías de agotamiento a pesar de la gran calidad del tomo XIV dedicado al final de la Edad Media, obra de Étienne Delaruelle, Paul Orliac y Edmond René Labande ${ }^{8}$. Tuvimos entre nosotros largas discusiones sobre lo que convenía hacer: unos pensaban que era suficiente con colmar los vacíos existentes en el «Fliche-Martin» poniendo al día los volúmenes más desfasados; otros opinaban que era mejor traducir al francés la «Kirchengeschicte» dirigida por Jedin, que suponía ya un progreso substancial $^{9}$. Finalmente, triunfó la idea, que yo había sostenido junto con otros desde

8 L'Église au temps du Grand Schisme et de la crise conciliaire, 1378-1449, en Étienne DELARUELLE, Edmond René LABANDE y Paul OuRLIAC (dir.), Histoire de l'Eglise: depuis les origines jusqu'à nos jours, fundada por Augustin Fliche y Victor Martin, t. XIV, 1-2, Paris, 1962-1964. En español: Espiritualidad y política en la Edad Media, t. 13; El gran cisma de Occidente, t. 15; La crisis conciliar, t. 16, en Historia de la Iglesia: de los orígenes a nuestros días, Edicep, Valencia, 1976-1977.

9 Hubert JEDIN (ed.), Handbuch der Kirchengeschichte, Freiburg im Breisgau, 1962-1979. En español: Manual de Historia de la Iglesia, 9 vols, Herder, Barcelona, 1966-1984. 
el principio, de crear ex novo una nueva colección con el significativo título de «Histoire du christianisme», dividida en 14 volúmenes: tres para la antigüedad, Edad Media y tiempos modernos y cuatro para la época contemporánea (17891989), más un volumen titulado Anamnesis que contenía una serie de estudios temáticos transversales y diacrónicos, así como una puesta al día bibliográfica. La casa editorial Desclée, de inspiración católica, aceptó publicar la colección en la que aparecieron todos los volúmenes entre 1990 y el $2001^{10}$. La empresa tuvo un cierto éxito y fue traducida al alemán por la editorial Herder ${ }^{11}$-hecho que nos enorgullecía puesto que la historia de la Iglesia había sido uno de los puntos más fuertes de la ciencia alemana-, y en italiano gracias a Giuseppe Alberigo y a las ediciones Borla ${ }^{12}$. Los responsables de las diferentes partes fueron Charles, y después de su muerte Luce Pietri, para la Antigüedad, yo mismo para la Edad Media, Marc Venard para los Tiempos Modernos y Jean-Marie Mayeur para la época contemporánea.

El círculo de colaboradores desbordó ampliamente el grupo de La Bussière, pero el espíritu que animaba a los responsables era fiel a las intuiciones fundamentales del Concilio Vaticano II que nosotros pretendíamos hacer prevalecer en el campo de la historia, como se puede observar en el texto programático que figura al principio del primer volumen: rechazo de la apologética y del recurso al sobrenaturalismo fácil, concepción de la Iglesia como Pueblo de Dios que peregrina hacia la ciudad de Dios, otorgar un gran espacio a los laicos pero sin exclusividad en razón de las estructuras institucionales y jerárquicas, aproximación ecuménica al cristianismo dentro de una visión plural que implique una apertura a todas las Iglesias que se reclaman a Cristo, comprendidas las que fueron declaradas heréticas por Roma a lo largo de los siglos, gran apertura hacia el Oriente cristiano (bizantinos, armenios, sirios, coptos...) que estaba ausente en las historias anteriores, así como atención a las misiones y a la Iglesias que se habían desarrollado fuera de Europa en época colonial, etc. En este sentido, y a pesar de las vicisitudes que ha conocido esta publicación, la Historia del cristianismo puede ser considerada como el punto de llegada y la realización más notable de la generación de historiadores cristianos -la mayoría de ellos católicos, aunque también había protestantes- a la cual yo he pertenecido.

\footnotetext{
10 Jean Marie MaYeur, Charles y Luce Pietri, André VAuCHEZ y Marc Venard (dirs.), Histoire du christianisme des origines à nos jours, 14 vols., Paris, 1990-2001.

11 Norbert Brox, Odilo ENGELS, Georg KRETSCHMar, Kurt MEIER y Heribert SMOLINSKI (eds.), Die Geschichte des Christentums, 3 vols., Freiburg im Breisgau, 2005.

12 Giuseppe Alberigo (ed.), Storia del Cristianesimo, 13 vols, Roma, 1997-2005.
} 


\section{ROMA Y EL DESCUBRIMIENTO DE ITALIA (FINALES DE 1965-1979)}

P. De una manera precoz, en $1964^{13}$, usted propuso (y se propuso) estudiar la bistoria religiosa de Occidente según una serie de perspectivas de estudio que ban tenido mucho éxito a la vez que han gozado de una gran libertad, quizás excesiva: hablamos de la historia de la predicación, la bistoria de la santidad, la bistoria de las prácticas religiosas de los laicos, la iconografía. Pero la primogénita fue la bistoria de la santidad e Italia-desde este punto de vista-el terreno adecuado para desarrollarla.

R. El otoño de 1965 ha significado un giro en mi vida y en mi carrera, puesto que en ese momento dejé Estrasburgo para transferirme a Roma como miembro de la École française donde podría seguir mis investigaciones durante tres años en el marco maravilloso del Palacio Farnesio. Mi nombramiento fue debido a mi condición de «normalier»-ya que en aquella época la Escuela solo reclutaba a antiguos alumnos de la Escuela Normal Superior o de la École de Chartes- y al apoyo de Michelle Mollat y Jacques Le Goff a mi candidatura.

Había estado en Roma como turista en 1958, más tarde, para trabajar durante mi año de master en 1960-1961 y había quedado fascinado por las riquezas de la Biblioteca Vaticana. Mi proyecto de investigación en la Escuela se centró en los procesos de canonización en la Edad Media y mis protectores no tuvieron dificultades en convencer al director de aquella época, el latinista Pierre Boyancé, de que este tema no podía ser tratado de manera satisfactoria sino con una estancia prolongada en Roma, aunque Boyancé me hizo notar la poca consideración que tenía hacía el «mal latín» de mis fuentes medievales... Pero la formación que había recibido conllevaba ciertas lagunas: no hablaba el italiano y debí aprenderlo rápidamente sobre la marcha para poder hablar con historiadores y bibliotecarias. Tampoco destacaba en paleografía, que había estudiado en la Sorbona, durante la licenciatura, con textos en francés antiguo, mientras que mi documentación romana estaba toda en latín. Después de un primer año un poco difícil, conseguí dominar lo suficiente la lengua italiana y sobre todo los escritos de los siglos XIII y XIV gracias a las enseñanzas de Giulio Batelli cuyo curso seguí en la Escuela de Paleografía del Vaticano, lo que facilitó en adelante, mis investigaciones y mis contactos con los usuarios -italianos pero también alemanes e ingleses-, del Archivo y de la Biblioteca Vaticana. En un pequeño ensayo lleno de humorismo, Nicolas Weill-Parot ${ }^{14}$ ha reflejado las

13 En el artículo programático ya citado.

14 Nicolas Weill-Parot, La magie des grimoires. Petite flânerie dans le secret des bibliothèques, Paris, 2009. 
angustias y las locas esperanzas de los jóvenes investigadores que frecuentaban estos lugares y se hacían desairar por los cancerberos predispuestos en contra y remisos a la entrega de la llave del armario, que era la que permitía acceder al «sancta sanctorum».

Las cosas sucedían de manera más tranquila en el segundo piso del Palacio Farnese, donde Noëlle de la Blanchardière hacía reinar en la Biblioteca de la Escuela un ambiente de lo más acogedor. Esta mujer extraordinaria, que no se ocupaba solo de los libros sino también de usuarios, se empeñaba en presentar a los miembros de la Escuela a los profesores e investigadores italianos que frecuentaban la biblioteca; gracias a ella, entré en relación con personas que podían darme consejos útiles para mis investigaciones. Y así, un buen día, me presentó a una tal Sofia Boesch Gajano cuyos intereses científicos -la hagiografía de la Alta Edad Media- eran muy parecidos a los míos, lo cual fue el origen de una larga amistad y una fecunda colaboración.

Pero el descubrimiento más importante que hice en mi primera estancia romana fue el de la historiografía italiana, y en particular la que se dedicaba a la historia religiosa de la Edad Media. Durante esos años, numerosas obras importantes vieron la luz dentro de este campo y yo quedé impresionado porque por esa misma época, en Francia, apenas se había empezado la renovación de ese tipo de estudios. Me lancé con pasión a leer los libros y artículos de Arsenio Frugoni, Raoul Manselli, Cinzio Violante, Giovanni Miccoli y otros. Sus trabajos respondían plenamente a mis expectativas en la medida en que otorgaban una gran espacio a la vida religiosa, a la vez que la ponían en relación con el contexto político, económico y social de la época estudiada, mientras que en Francia estos dos polos seguían ignorándose mutuamente: la historia de la Iglesia se presentaba a menudo como una especia de telón de fondo o decorativo delante del cual los protagonistas desarrollaban su actuación con un objetivo puramente espiritual; por otra parte, la «gran historia» universitaria, fuertemente marcada por el marxismo y sobre todo por el estructuralismo, despreciaba los hechos y sucesos religiosos, considerándolos como insignificantes o marginales. Además, tuve la ocasión de coincidir con algunos de estos grandes maestros que me impresionaban mucho y, en algunos casos, conocerlos personalmente. En Italia, a diferencia de lo que pasaba en Francia en esa misma época, ya existía una gran cantidad de coloquios importantes en las materias que me interesaban particularmente $y$ comencé a asistir a las «semanas» de La Mendola, de Todi, de Asís e incluso de Espoleto, donde tuve que volver, hasta el día de hoy, tanto como oyente «con más frecuencia como conferenciante. Su asistencia asidua me permitió encontrarme con algunas de las grandes figuras de la historiografía europea: aparte de 
los ya mencionados, Dom Jean Leclercq y Dom Jean Becquet, dos monjes benedictinos e historiadores franceses llenos de ciencia y humanidad, el P. Gy, el P. Gilles-Gérard Meerssemann, op, Gerd Tellenbach, Jean-François Lemarignier, Christopher Brooke, Giles Constable, Jerzy Kloczowski, Cosimo Damiano Fonseca, Ovidio Capitani, Giovanni Tabacco y tantos otros que sólo conocía por mis lecturas y que más tarde me honraron con su cariño y, en algunos casos, a pesar del salto generacional, con su amistad.

P. Según su propia experiencia, ¿cuándo se ha producido la relación con la antropología «religiosa» italiana, y en particular con las investigaciones de Ernesto de Martino? En el prefacio de la traducción italiana de Sainteté en Occident aux deniers siècles du Moyen Âge (La Santità nel medioevo), redactado en 1988, usted recuerda baber «tenido la impresión de que su papel no era en absoluto el de aquel que intenta resucitar sin más un pasado ya cerrado» porque la veneración por los santos «nunca ba dejado de existir» en Italia. Bajo este aspecto, ¿¿cuál es su percepción de las diferencias entre el Sur y el CentroNorte de Italia?

R. Durante esos mismo años, y aún más durante mi segunda estancia romana (1972-1979), empecé a viajar por Italia, solo o con la familia, y me di cuenta rápidamente de que, en numerosas regiones, las formas «tradicionales» de la vida religiosa estaban aún vivas: bastaba con viajar a 90 kilómetros de Roma, hacia el norte, esto o sur, para sumergirse en un mundo en vías de transformación pero que conservaba aun los rasgos fundamentales de la civilización rural que en ocasiones se remontaban al período medieval. Quedé muy tocado por la persistencia de ciertas formas de religiosidad popular, en particular por las procesiones y las fiestas en honor de los santos que estaban muy vivos en la memoria de las gentes tanto en Sabina como en los Abruzos o en la Ciociaria. Mientras que en Francia las manifestaciones de este género habían desaparecido o estaban en vías de extinción o eran puro folclore turístico, en Italia parecían sólidamente enraizadas y encontraban una fuerte adhesión. De esta manera, tuve la suerte de poder establecer una relación entre mi tema de investigación -la santidad y el culto a los santos en la Edad Media- y las manifestaciones de la devoción hacia estos últimos, empezando por la Virgen María, lo cual me condujo a interesarme por la «religión popular» siguiendo las huellas de Étienne Delaruelle, y de modo particular, en el papel de los santuarios dentro de la vida religiosa. Para resumir estos recuerdos, que con el paso del tiempo se han desdibujado un poco, diré que la Italia de los años 70 me ha parecido como una especie de conservatorio de formas de vida y de prácticas religiosas que en Francia habían desaparecido pero que aún se podían estudiar no lejos de Roma. Sin embargo, yo no pretendía estudiarlas como lo haría un etnólogo, aunque 
es en esta época cuando he descubierto, a través de los libros de De Martino y por la observación directa, todo lo que la perspectiva etnológica podía aportar al historiador.

P. Su regreso a Francia ¿marca una ruptura en sus relaciones científicas y académicas con Italia?

R. A mi regreso a Francia, en el verano de 1968, fui contratado por la Sorbona (aún indivisa) como «assistant», y más tarde como «maitre-assistant» en Historia de la Edad Media, gracias a mi maestro Michel Mollat. Este primer contacto con la enseñanza superior fue un poco duro pues llegué a Paris justo después de los sucesos del mayo francés que habían dejado mucha huella en las personas y heridas en los corazones de ciertos colegas, jóvenes y menos jóvenes. Por otra parte, enseguida tuve que poner exámenes, durante todo el mes de octubre, sobre cuestiones que yo no había impartido y sobre las cuáles no sabía mucho más de lo que sabían los propios estudiantes... Una vez pasada esta agitada incorporación, las cosas se calmaron y estuve en disposición de concentrarme en mi trabajo. La enseñanza me gustaba mucho e hice grandes esfuerzos para convencer a mis alumnos de que la Edad Media era tan importante para ellos como lo era la historia contemporánea.

Además del seminario de Michel Mollat sobre «Les pauvres et la pauvreté au Moyen Âge», reencontré en la Sorbona a Jean-François Lemarignier, profesor de historia del derecho medieval, que había conocido en una de las «Settimana» de La Mendola. Él estaba muy unido a Cinzio Violante, compartiendo sus puntos de vista sobre la sociedad feudal, y éste último le pidió escribir el prefacio de una recopilación de estudios publicados en Milán, en 1971, bajo el título de Studi sulla cristianità medioevale ${ }^{15}$. Esta petición le supuso un cierto embarazo pues aunque admiraba la obra de su colega y amigo, no conocía más que algunos aspectos de su obra histórica. De esta manera, me pidió si podíamos escribir «a cuatro manos» este prefacio y esto me granjeó la simpatía de Violante y de su entorno, aunque algunos años más tarde el maestro de Pisa me como un «pequeño representante del sesenta y ocho» debido al disgusto producido por uno de mis artículos... De todas maneras, este prefacio me valió en Italia la reputación -claramente inmerecida- de ser un buen conocedor de la historiografía italiana, mientras que yo era simplemente un investigador debutante que había tenido la fortuna de frecuentar tempranamente la corte de los grandes...

15 Cinzio Violante, Studi sulla cristianità medioevale. Società, istituzioni, spiritualità, Milano, 1972. 


\section{LA ESPIRITUALIDAD DE LA EDAD MEDIA OCCIDENTAL (EN FRANCIA, EN ITALIA)}

P. Recorriendo su vasta bibliografía, es fácil constatar que la mayor parte de los estudios hacen referencia a la Edad Media central y a la baja Edad Media, avalando la revolución teológica del siglo XII, que Chenu habia puesto como centro de sus reflexiones. ¿Es erróneo pensar que el joven André Vauchez, con La spiritualité du Moyen Âge occidental (VIII -XII ${ }^{\mathrm{e}}$ siècle), editada en 1975 pero rápidamente traducida con éxito en Italia, haya querido de alguna manera «finiquitar» con la Alta Edad Media o al menos ajustar cuentas con ella? ${ }^{16}$ ¿Cuál ha sido la espiritualidad de los laicos de los siglos VIII a XII? ¿ Una espiritualidad sin «consciencia» individual? Y, en todo caso, que significó este libro en el conjunto de su producción? ¿Fue una consecuencia natural de su trabajo de tesis doctoral sobre la santidad medieval?

R. Esos años parisinos estuvieron marcado sobre todo por la preparación y la redacción de mi primer libro La spiritualité du Moyen Âge occidental (VIII ${ }^{e}-X I I^{e}$ siècle), publicado en Paris en 1975 y en 1978, en italiano, en Milán en la editorial Vita et Pensiero, con una excelente traducción, siendo reeditado en 2006 con un importante prefacio debido a Giorgio Cracco donde analiza el contenido de la obra con entusiasmo y agudeza ${ }^{17}$. Esta obra ha tenido una amplia difusión y fue reeditada en 1996 con el añadido de un capítulo suplementario sobre el siglo XIII. De alguna manera, el libro ha conocido una segunda vida y es usado aún por los estudiantes.

En efecto, este éxito le ha sobrevenido en gran medida por que el libro es, en su esencia, fruto de mi docencia universitaria del período 1968-1972 en la Sorbona y de las lecturas que hice durante aquellos años. Teniendo que enfrentarme con jóvenes que en su mayoría no tenían la mínima cultura religiosa, me obligó a exponer con precisión el sentido de las nociones teológicas, doctrinales o litúrgicas que usaba y rendir cuentas de su contenido en términos inteligibles para el «hombre de la calle», lo que fue muy apreciado por mis lectores. Pero, si hay que hace caso a las recensiones que se hicieron cuando salió la obra, la principal novedad, de esta pequeña síntesis, residía en la introducción de la «espiritualidad» en el campo histórico.

16 «Incapaces de acceder a la abstracción, los laicos han tendido a trasladar al registro emotivo los misterios fundamentales de la fe»: La spiritualité du Moyen Âge occidental, p. 9.

17 Giorgio GRACCO, Introduzione, en André VAUCHEZ, La spiritualità dell'Occidente medioevale, Milano, $1993^{2}$, pp. IX-XXII. La obra se encuentra en español con el título, La espiritualidad del Occidente medieval: (siglos VIII-XII), Cátedra, Madrid, ${ }^{3} 2001$. 
El término no era nuevo, como testimonia el hecho de que desde los años 30 existía un «Dictionnaire de spiritualité ascétique et mystique», publicado por los jesuitas franceses y que no se acabó hasta $1994^{18}$. Existía, igualmente, una revista ligada al «Dictionnaire de spiritualité» y a los jesuitas, la «Revue d'ascétique et mystique», donde se publicaron numerosos textos inéditos y estudios históricos y literarios relativos a las diversas formas de la vida espiritual. En 1970, su director, Jean-Claude Guy, excelente conocedor de los Padres del desierto, me invitó a participar en el comité editorial de la revista que cambiaba su nombre, entonces, por el de «Revue d'histoire de la spiritualité». Rápidamente, me hice amigo de los pilares de la revista: Émile Guichot, profesor de literatura francesa en la universidad de Estrasburgo y amigo de Gabriele de Rosa -que trabajaba sobre el abbé Brémond, Giuseppe de Luca y el modernismo-, y con Michel de Certeau, historiador de la mística del XVII, de quien descubrí, entonces, su inmensa cultura y su capacidad asombrosa de dialogar con todas las culturas y las personas más diversas. Para nosotros, la espiritualidad no era una noción teológica, ni una manera de evocar las grandes figuras de la historia espiritual de la humanidad, saltando de san Anselmo y san Bernardo a Francisco de Asís y Tomás de Aquino, como había hecho el gran medievalista belga Léopold Génicot en un libro de $1951^{19}$ para mostrar los frutos perfectos que podía dar «una civilización católica europea fundada sobre el bien y la verdad», según su objetivo propuesto. Según mi punto de vista, como explicaba en la introducción, la espiritualidad era más bien «la unidad dinámica de una fe y la manera en que era vivida por los hombres históricamente determinados», lo que justificaba su extensión a los laicos, mientras que parecía debería estar reservada al clero y a los religiosos. También hablé de la espiritualidad popular que para mí no era un conjunto confuso de prácticas y devociones más o menos supersticiosas, como se podía tender a imaginar, sino una concepción de Dios y de las relaciones entre el hombre y lo sagrado que asociaba a las creencias fundamentales del cristianismo otros elementos ligados a la mentalidad y a la cultura de su medio. Esta espiritualidad de los laicos se distinguía de la de los clérigos por una marcada tendencia a trasladar los misterios de la fe a un registro demostrativo y visual.

Con el tiempo, me parece que ciertos aspectos de este libro, que durante los años 1975-1980 podían parecer novedosos, ahora son ampliamente aceptados. Así, la afirmación de que, al menos a partir del siglo XII, existía una espiritualidad

18 Dictionnaire de spiritualité ascétique et mystique. Doctrine et histoire, Paris, 1932-1995.

19 Léopold GÉNICOT, Les lignes du faîte du Moyen Âge, Tournai, 1951. 
de los laicos conviviendo con la de los monjes -idea que podía parecen entonces una reivindicación polémica-, ha pasado al acervo común de los historiadores. Lo testimonian los numerosos estudios que después se han consagrado a los «laicos religiosos» $\mathrm{y}$ a las beguinas, a las cofradías de la caridad y devocionales, a las instituciones asistenciales creadas y regidas por burgueses de las ciudades y -last but not least- a la religión cívica.

Después del Concilio Vaticano II, la Iglesia católica se encuentra frente al problema de lo que se llamaba en aquellos momentos la «religión popular», noción que fue el centro de numerosos debates y polémicas en Francia pero que terminó por imponerse a finales del siglo pasado. Este concepto me parece válido siempre que las formas de devoción y piedad que engloba no sean consideradas como la supervivencia o el camuflaje de una «cultura folclórica» extraña al cristianismo, ni como un reflejo empobrecido de la vida y de la cultura religiosas de los clérigos sino como una vía de acceso auténtico al mundo sobrenatural para la gran mayoría de los fieles que ignoraban el latín y que no sabían ni leer ni escribir. Desde la aparición de «La spiritualité du Moyen Âge occidental», se han hecho grandes progresos en esta temática: en esa época, la aproximación a la espiritualidad pasaba únicamente por los textos y los escritos. Hoy día, gracias a los trabajos de Jérôme Baschet, Chiara Frugoni, Jeffrey Hamburger, Michele Bacci, Dominique Rigaux y de otros, las investigaciones basadas en las fuentes iconográficas se han revelado como muy fecundas, lo cual, con la digitalización que ha propiciado la constitución de un vasto corpus de imágenes, ha conllevado un aumento considerable de la documentación a disposición de los investigadores.

P. En Italia, La spiritualité du Moyen Âge occidental, es acogida positivamente y traducida casi inmediatamente ${ }^{20}$. En su opinión, ¿Por qué se da este hecho?

R. La acogida favorable de mi pequeño libro, sobre todo en Italia, es debida, sin duda, al hecho de que sacaba la religiosidad de las «clases subalternas», como decían entonces los autores marxistas, de visiones simplistas que la reducían a una forma de protesta social o de retraso cultural. Diciendo esto, no pretendo negar las contribuciones del pensamiento de Gramsci y los estudios admirables de De Martino sobre el Mezzogiorno italiano. Pero, como yo no podía aceptar sus lecturas simplificadoras de la religión popular, yo me aliste bajo la bandera de Gabriele de Rosa que, en sus estudios sobre $\ll$ Sud et magie ${ }^{21}$, había sabido tener

20 Gracias a la intervención de D. Piero Zerbi con la casa editorial «Vita e pensiero».

21 Gabriele DE ROSA, Vescovi popolo e magia nel Sud. Ricerche di storia socio-religiosa dal XVII al XIX secolo, Napoli, 1971. 
las dos riendas y hacer historia social sin sacrificar la dimensión religiosa de los fenómenos estudiados.

P. Durante el tiempo que usted ha dirigido la sección medieval de la École Française de Roma, nació, en 1974, el Círculo medievalista romano, a cuyo nacimiento y desarrollo ba contribuido de manera determinante, lanzando la idea, en colaboración con Gilmo Arnaldi y el director del Instituto germánico de Roma, Reinhard Elze $e^{22}$. ¿Se trataba de un encuentro entre instituciones o más bien un encuentro en torno a diferentes temas de investigación (la villa comunal, las órdenes mendicantes...)?

R. A finales de 1972 regresé a Roma como director de los estudios medievales de la Escuela Francesa de Roma. Se trataba de un nuevo puesto, creado por petición del director de la época, Georges Vallet, que había decidido crear tres secciones en la Escuela consagradas respectivamente al estudio de la Antigüedad, de la Edad Media y de las épocas moderna y contemporánea. Los años que siguieron a este regreso inesperado (1972-1979) fueron sin duda los más importantes de mi carrera: por un lado, me tuve que ocupar de los miembros medievalistas y becados de la Escuela, crear una nueva serie de Mélanges dedicada a los estudios medievales y desarrollar un programa de investigaciones históricas y arqueológicas en contacto con las universidades y las superintendencias italianas para las excavaciones medievales que se multiplicaban en el Latium y en el sur de Italia; por otra parte, quería terminar y defender mi tesis de Estado que debía permitirme obtener un puesto de profesor dentro de una universidad francesa cuando regresara a mi madre patria.

No era sencillo hacer frente a estas exigencias contradictorias y este periodo de mi vida fue ciertamente uno de aquellos en los que sufrí fuertes tensiones. Pero a la vez, fue la época más productiva, en la medida en que pude ir hasta el fondo de mis intuiciones y de mi proyecto de estudio sobre la santidad medieval. Pero antes de abordar este último punto, quiero subrayar la gran fecundidad de la iniciativa tomada en 1973 con Gilmo Arnaldi, profesor de historia medieval en La Sapienza y director del Istituto italiano per il Medioevo, y con Reinhard Elze, director del Instituto Histórico Alemán, de crear el «Circolo medievistico romano». La idea consistía en reunir periódicamente a los medievalistas italianos y extranjeros residentes en Roma para invitarles a discutir juntos en torno a una exposición de algunos de los temas sobre los que estaban investigando. En este marco se anudaron grandes amistades, un gran número de ideas y de informaciones fueron intercambiados y el hecho de que este «Circolo» exista aún hoy día es suficiente, me parece, para ilustrar su utilidad tanto en el plano intelectual como en el social.

22 Circolo medievistico romano, en Melanges de l'École Française de Rome, 103/1 (1991), pp. 448-451. 


\section{LA SANTIDAD EN OCCIDENTE EN LOS ÚLTIMOS SIGLOS DE LA EDAD MEDIA}

P. Llegamos a La sainteté en Occident aux derniers siècles du Moyen Âge. Como ya se ba dicho, se trataba de un proyecto que se babía iniciado bacía ya un tiempo y que habia madurado en la década de los sesenta.

R. Lo esencial de mis esfuerzos estuvo consagrado a la redacción de mi tesis sobre «La sainteté en Occident aux derniers siècles du Moyen Âge» que defendí en julio de 1978 delante de un tribunal compuesto por Michel Mollat, Jacques Le Goff, Georges Duby, Pierre Toubert y Robert Foltz. La defensa, en la Sorbona, duró más de seis horas y acabé exhausto pero feliz. El libro que salió de la tesis fue publicado por la Escuela Francesa de Roma en 1981 y traducido, en una versión abreviada en italiano (Il Mulino, Bolonia, 1989) y en inglés (Cambridge University Press, 1997) ${ }^{23}$.

Para comprender la génesis de esta obra que estuvo en el centro de mis preocupaciones durante más de diez años, hay que remontarse a los años 60 . Me parece -aunque es un recuerdo débil- que la elección de este tema fue el resultado de una conversación que tuve con Charles de La Roncière que me había hecho notar que, dentro de la historia de los modelos de santidad en Italia, existía un gran vacío para los siglos XIII al XVI, y por lo tanto se podía rellenar esa laguna. La elección del tema fue aprobada por Mollat y Le Goff que me animaron a adentrarme por esta vía poco frecuentada.

No era, por lo tanto, fácil hacerse un hueco en el campo de los estudios hagiográficos que parecían reservados a bolandistas y filólogos. De hecho, cuando ya estaba en Roma, en 1960-61, para hacer mis primeras investigaciones sobre los procesos de canonización medievales sobre los que tenía intención de trabajar, visité, a sugerencia de Jacques Le Goff, a un gran erudito dominico, el P. Marie-Hyacinthe Laurent, editor del proceso de canonización de santa Catalina de Siena, para exponerle mis proyectos y pedirle consejos. Su respuesta me dejó helado pues me dijo que en los procesos de canonización no encontraría nada importante que no estuviera ya en las vidas de los santos en cuestión; añadiendo que, como yo no era ni teólogo ni canonista, no sería capaz de conocer y comprender la idea que los hombres de aquella época tenían de la santidad... Muy disgustado por estas observaciones, sin embargo no me desanimé y empecé por leer los

23 La sainteté en Occident aux derniers siècles du Moyen Âge d'après les procès de canonisation et les documents hagiographiques, Roma, 1981 (Bibliothèque des Écoles françaises d'Athènes et de Rome, 241), y ${ }^{2}$ 1988, ${ }^{3}$ 1994; traducción italiana, La Santità nel Medio Evo, Bologna 1989; traducción inglesa, Sainthood in the Later Middle Ages, Cambridge, 1997. 
procesos de canonización editados, antes de pasar, en los años 1965-68, a los que estaban aún inéditos -más numerosos-.

Había elegido estudiar este tipo de documentos, hasta ahora desatendidos por los historiadores, porque me parecía que constituían un lugar de encuentro entre la mentalidad de los clérigos que habían redactado los articuli interrogatorii y conducían los interrogatorios, y los de los testimonios entre los cuales figuraban muchos laicos a menudo illitterati, en el sentido medieval de esta palabra. Este cruce de aproximaciones -no siempre concordantes- sobre la santidad por parte de unos y de otros me parecía interesante; como joven intelectual cristiano comprometido con el movimiento de reforma promovido por el Concilio Vaticano II, estaba convencido de que uno de los mayores problemas de la Iglesia católica era el de su clericalización y marginalización en su seno del elemento laical, que se había acentuado a partir de Trento pero cuyos orígenes se remontan al mundo medieval. Desde este punto de vista, el «diálogo» iniciado en la Edad Media entre clérigos y laicos acerca de la santidad era tan significativo que la santidad no podía ser ratificada por la jerarquía eclesiástica si no existía un mínimo de enraizamiento popular, atestiguada por los milagros. Como historiador fascinado por la historia de las mentalidades, que estaba entonces despuntando siguiendo la línea de Annales y en la cual había sido iniciado por Jacques Le Goff, yo buscaba en los procesos las huellas de un contraste, sino un enfrentamiento, entre diversos tipos de mentalidades con ocasión del reconocimiento de la fama sanctitatis de un hombre o una mujer después de un lapso de tiempo relativamente breve desde su muerte. Por último, deseaba igualmente medir la consistencia y las modalidades de difusión de esta fama desde la perspectiva sociológica que me habían enseñado Gabriel Le Bras y sus alumnos dentro del marco de los Archives de sociologie religieuse del CNRS (hoy día: Archives de sciences sociales des religions), revista en la cual había colaborado durante bastantes años publicando reseñas de libros, lo cual me ayudó a ampliar mi cultura. Para resumir, podría retomar la frase de mi introducción a La sainteté en Occident (p. 1) donde hablaba de mi ambición «de hacer entrar en el territorio del historiador esta terra incognita que había sido desde hacía mucho tiempo la historia de la santidad $\gg^{24}$.

P. En la introducción a La sainteté en Occident aux derniers siècles du Moyen Âge, usted rindió homenaje a los estudios de Frantisek Graus, de Karl Bosl, de Friedrich Prinz, etc, que «permitieron hacer entrar en el territorio del bistoriador la bistoria de la santidad, esa tierra desconocida desde hacía tanto tiempo», gracias a la ilustración de las

24 André VaucheZ, La sainteté en Occident, p. 1. 
relaciones entre los modelos ideales propuestos, la mentalidad y las estructuras sociales y políticas. En el curso de esos mismos años, otros eminentes investigadores han desarrollado un cierto interés por la hagiografía: por ejemplo, Sofia Boesch Gajano, que con su antología hagiográfica medieval (Hagiographie du Haut Moyen Age) puso en circulación nuevas sensibilidades, pero también Evelyn Patlagean y Peter Brown...

R. Digamos, antes que nada, que yo no era el único, en aquellos tiempos, interesado en el estudio de las fuentes historiográficas y en el culto a los santos: Frantisek Graus venía de publicar su obra Volk, Herrscher und Heiliger im Reich der Merowinger ${ }^{25}$, que descubrí con ocasión de un seminario de J. Le Goff en el que él vino a presentarlo en 1965; el mismo año, Karl Bosl publica un importante artículo (Der Adelsheilige. Idealtypus und Wiklichkeit) ${ }^{26}$ y en 1968 aparece en Annales, el de Évelyne Patlagean titulado $A$ Byzance: ancienne hagiographie et histoire socia$l e^{27}$; en 1975 ve la luz el libro del medievalista canadiense Joseph-Claude Poulin sobre L'idéal de sainteté dans l'Aquitaine carolingienne ${ }^{28}$, y en 1976, la antología de Sofia Boesch Gajano titulada Agiografia medievale ${ }^{29}$. Este último, además de la riqueza de su puesta al día historiográfica y bibliográfica, constituye una especie de manifiesto de la «nouvelle histoire» en el campo de los estudios históricos fundados sobre las fuentes historiográficas. En 1981, una primera cosecha de estos trabajos pioneros fue recolectada con ocasión del coloquio organizado por Paris X-Nanterre por Évelyn Patlagean y Pierre Riché sobre la hagiografía de la alta edad media ${ }^{30}$, a la vez que aparecía la obra fundamental de Peter Brown sobre The Cult of the saints. Its Rise and Function in Latin Christianity ${ }^{31}$, en 1981, el mismo año de la publicación de mi tesis sobre La sainteté en Occident aux derniers siècles du Moyen Âge.

Esta primavera historiográfica excepcional no era fruto del azar sino que correspondía a un doble cambio que se había producido en la aproximación a la

25 Frantisek GRAUS, Volk, Herrscher und Heiliger im Reich der Merowinger: Studien zur Hagiographie der Merowingerzeit, Praha, 1965.

26 Karl BosL, Der «Adelsheilige». Idealtypus und Wiklichkeit, Gesellschaft und Kultur im merowingerzeitlichen Bayerns des 7. Und 8. Fabrhunderts, en Speculum bistoriale, Festchrift 7. Spörl, Freiburg im Breisgau, 1965, pp. 167-187.

27 Évelyne PatlagEan, À Byzance: ancienne hagiographie et histoire sociale, en Annales. Economies, Sociétés, Civilisations, 23 (1968), pp. 106-126.

28 Joseph-Claude POULIN, L'idéal de sainteté dans l'Aquitaine carolingienne d'après les sources hagiographiques (750-950), Quebec, 1975.

29 Sofia Boesch Gajano (ed.), Agiografia medievale, Bologna, 1976.

30 Évelyne PatlagEAN-Pierre RICHÉ (eds.), Hagiographie, cultures et sociétés (IV ${ }^{e}-X I I^{e}$ siècle), Paris, 1981.

31 Peter Brown, The Cult of the saints. Its Rise and Function in Latin Christianity, Chicago, 1981. 
santidad: de un lado, sobre el plano religioso, un cierto tipo de discurso hagiográfico y apologético, tributario del romanticismo del siglo XIX más que de la Edad Media en la medida en que tomaba al pie de la letra los relatos más fabulosos bajo el falso pretexto de que «nada es imposible para Dios», era insostenible después del Vaticano II; por otro lado, la historiografía laica, gracias a sus grandes personalidades como Marc Bloch, con sus Rois thaumaturges, Robert Foltz y Jacques Le Goff, había superado las desconfianzas que habían llevado a los historiadores positivistas a recelar de las fuentes hagiográficas; el historiador ya no podía contentarse con poner mala cara delante del enorme filón documentario que constituyan las vidas de los santos y las recopilaciones de milagros que la Edad Media nos había dejado en gran número. La cuestión ya no era si los santos a los que se les atribuyan tal cantidad de virtudes y prodigios habían o no existido, o si los milagros que se les atribuyan habían sido inventados por los clérigos que los habían recopilado, sino más bien qué concepción de la santidad se vehiculaba a través de esos relatos y en qué medida las representaciones presentadas habían sido recibidas y compartidas por los medios sociales y culturales a los que se dirigían.

P. En los años que siguen a la publicación de La sainteté en Occident aux derniers siècles du Moyen Ầge, los estudios hagiográficos han cambiado profundamente. ¿Podríamos hablar de un retorno al texto, al texto estudiado iuxta propria principia, poniendo el foco de atención sobre las «estructuras» del estructuralismo literario más que sobre las estructuras sociopolíticas? Usted mismo, desde que se ocupa de este campo, las ba reconducido a unas fuentes concretas, es decir, a los procesos de canonización ${ }^{32}$.

R. Los trabajos que he citado con anterioridad se referían a la Antigüedad tardía y a la Alta Edad Media. Por mi parte, siguiendo la misma problemática pero adaptándola a una época diferente, centré mi interés en los últimos siglos de la Edad Media, en la medida en que los esfuerzos del papado por establecer nuevas normas en el culto de los santos a través de los procesos de canonización y por canalizar las riadas algunas veces problemáticas de la religiosidad popular, me permitían abarcar un proceso de desdoblamiento de la santidad en dos sectores: el de la santidad oficial -la santidad «moderna»- que proponía figuras de santos imitables y generalmente cercanos en el tiempo tanto a los clérigos como a los laicos, y el de la santidad tradicional (diría «popular», aunque la expresión es ambigua) que quedaba ligada a los modelos antiguos y que otorgaba mucha importancia a los poderes milagrosos de los siervos de Dios. Igualmente, traté de

32 L'influence des modèles hagiographiques sur les représentations de la sainteté dans les procès de canonisation, en Évelyne PatlagEan y Pierre RichÉ (eds.), Hagiographie, cultures et sociétés, pp. 585-596. 
mostrar que más allá de esta divergencia, existían algunos rasgos de mentalidad comunes a todos los medios sociales y culturales que, en ausencia de criterios científicos objetivos, daban mucha cancha a las intervenciones sobrenaturales en la vida de los hombres y asociaban casi siempre lo imaginario a lo ejemplar y lo maravilloso al dominio moral y espiritual, como lo ejemplifica bien el rápido éxito de la representación de los estigmas de san Francisco de Asís en la iconografía occidental. Desde esta perspectiva, los procesos de canonización deben ser menos considerados como intentos de racionalización de la santidad -incluso si esta dimensión está presente- que como expresión de la voluntad del papado de debilitar las prerrogativas de los obispos en el campo del culto a los santos y de extender el control de la Iglesia a todos los aspectos de la vida religiosa de los fieles, incluyendo la elección de sus protectores celestes, a través de la difusión en el seno del pueblo cristiano de nuevos modelos de santidad.

Si debiera rescribir este libro ex novo, pondría más el acento (de lo que lo hice entonces) en los aspectos jurídicos del procedimiento -el P. Laurent no se equivocaba cuando me decía que yo no tenía la suficiente formación canónica-, sobre el papel de los traductores y de los notarios en el registro de las deposiciones de los testimonios y sobre la dimensión cultural de estas grandes encuestas que apenas vengo de nombrar. Por otra parte, desarrollaría la comparación esbozada en el inicio de la obra entre el proceso de canonización promovido por el papado y las encuestas organizadas en su reino por los soberanos inglés y francés a partir de mediados del siglo XIII, aunque es cierto que, en ambos casos, la inquisitio in partibus tenía como objetivo no tanto conocer el estado exacto de la opinión pública en todos sus componentes, que hacer aprobar por ésta el «discurso del poder» eclesiástico o laico. En contraposición, reduciría sin dudarlo la segunda parte del libro titulada «Typologie de la sainteté officielle: aspects quantitatifs», que se resiente demasiado de la influencia de la sociología religiosa preconizada por Gabriele Le Bras -cuyos métodos fundados sobre el censo de los católicos practicantes eran válidos para el siglos XX, pero no para la Edad Media- y de la historia cuantitativa difundida por la Escuela de Annales precisamente en los años en que yo redactaba mi tesis. En ese capítulo hay un exceso de cifras y porcentajes que no son demasiado significativos, puesto que se apoyan en bases estadísticas más bien pobres. Ahora me doy cuenta de que el deseo de cuantificar a cualquier precio la evolución de la santidad medieval me ha desviado de mi meta y que esta noción es demasiado sutil y compleja como para hacer de ella el objeto de una aproximación global, tal como hicieron los historiadores americanos Donald Weinstein y Rudolph Bell en su libro Saints and Society. The Two Worlds of Western Christendom, 1000-1700, publicado en 1982. 
P. ¿Qué acogida tuvo su tesis en Italia y en los países anglófonos? ¿Cómo se ba ido definiendo su posición historiográfica en el clima cultural francés de los años 90 ?

R. Mi libro tuvo un amplio eco, en particular en Italia en la medida en que allí existían una gran cantidad de santos, de los más desconocidos a los más célebres, que nunca habían sido estudiados desde esta perspectiva, y el papel jugado por las órdenes mendicantes en la formación y difusión de un nuevo santoral adaptado a las expectativas de las sociedad urbana. También suscitó curiosidad en los Estados Unidos en razón de los desarrollos consagrados a las nuevas formas de la santidad femenina que interesaban sobre todo a los sostenedores de la «Gender History», como pude apreciar con motivo de una conferencia que yo hice en 1982 o 1983 en la Universidad de Columbia, delante de un público mayoritariamente femenino. También los especialistas de historia política eran sensibles a lo que podía aportar mi tesis respecto a la santidad de los reyes y de la fortuna del tema de la beata stirps respecto a ciertas dinastías como los Angevinos de Nápoles y de Hungría a partir del siglo XIV. Por lo demás, tuve la ocasión de retomar y desarrollar algunos de estos temas en el marco de los coloquios organizados por la École Française de Rome y por la Universidad Paris X-Nanterre sobre Faire croire (1981), La religion civique (1995), L'érémitisme (2003), etc. ${ }^{33}$. cesas?

P. ¿Cómo se sitúa usted en relación a las distintas corrientes historiográficas fran-

R. En los años siguientes, me fui alejando, progresivamente y sin polémicas inútiles, de los Annales donde había publicado algunos de mis primeros artículos sobre la pobreza medieval y la renovación de la historiografía religiosa de la Edad Media, entre 1970 y 1973. Desde mi punto de vista, esta corriente historiográfica tendía a abusar y a mirar por encima del hombro a los universitarios «tradicionales» como se decía por aquella época en el EHESS (École des Hautes Études en Sciences Sociales)... Por otra parte, la gran mayoría de los sostenedores de esta escuela, muy marcados por el marxismo o el estructuralismo, no querían dar espacio a los factores religiosos y no reconocían su importancia en el campo histórico. Jacques Le Goff, por ejemplo, a quien yo estaba ligado por una sólida amistad, al igual que por un afectuoso reconocimiento por todo lo que me había aportado, no usaba la documentación relativa a las órdenes mendicantes sino para llegar a una definición de la noción de villa en la Francia medieval y para apreciar la importancia de cada centro urbano en función del número de conventos de Mendicantes que

33 Faire croire. Modalité de la diffusion et de la réception des messages religieux du XIII au XVe siècle, Roma, 1981; André VAUCHEZ (dir.), La religion civique à l'époque médiévale et moderne (Chrétienté et Islam), Roma, 1995; Ermites de France et d'Italie (XI $-X V^{e}$ siècles), Roma, 2003. 
estaban allí establecidos. De igual modo, Jean Claude Schmitt y sus discípulos han estudiado durante decenios los exempla medievales y sus colecciones tratando de encontrar en esos relatos edificantes utilizados por algunos predicadores en sus sermones, huellas de la presencia y de la influencia de una «cultura folclórica» extraña al cristianismo. Lejos de mí la idea de contestar el interés y la utilidad de esas investigaciones fundadas esencialmente sobre las producciones de los frailes mendicantes; pero encuentro un poco ligera esta aproximación a las fuentes y a las creencias religiosas, como si ellas constituyeran solamente una «cobertura» ideológica bajo la cual un mundo totalmente distinto llevara una especie de vida paralela subterránea. Bajo este punto de vista, me he sentido más cercano a la historiografía italiana que a la francesa en la medida en que la primera tomaba más en serio y trataba con más respeto la dimensión religiosa del hombre, sin prejuicio discriminadores. Me parece que la evolución que ha conocido el mundo después de veinte años me ha dado la razón, visto que la importancia de los factores religiosos en la vida política, social y cultural de Europa y del mundo, lejos de disminuir, no ha hecho más que crecer, mientras que la ceguera intelectual de los intelectuales franceses, marcados, la mayor parte, por un laicismo intolerante, no les ha permitido analizar correctamente las evoluciones en marcha ni afrontarlas con eficacia.

\section{LOS GRANDES TEMAS: LA «ESPACIALIZACION DEL CRISTIANISMO»}

P. ¿Puede hablarnos de la evolución de su pensamiento respecto a la relación entre el espacio y la religión, pensamiento que se ba concretado a través de los grandes proyectos de investigación colectiva que usted ha animado como por ejemplo L'espace, l'homme et le sacré dans le monde méditerranéen? En este contexto, ¿¿ómo se puede interpretar el papel de los santuarios? Se puede subrayar que en un ensayo publicado recientemente, la «espacialización de lo sagrado» ${ }^{34}$ ba sido considerado como la clave de lectura decisiva de la historia religiosa de Occidente; pero nos parece que es el «espacio» italiano el que, una vez más, ha jugado un papel de «taller experimental» para sus trabajos.

R. En este tema es necesario hacer justicia a los escritos de Alphonse Dupront y en particular a su gran libro titulado Du sacré. Croisades et pèlerinages, images et langages $(1987)^{35}$. Este eje de mi investigación se desarrolló sobre todo

34 André VAUCHEZ (dir,), Lieux saints et pèlerinages: la spatialisation du sacré dans l'Occident chrétien (IX'-XII siècles), en I santuari cristiani d'Italia. Bilancio del censimento e proposte interpretative, Roma, 2007, pp. 3-15.

35 Alphonse Dupront, Du sacré. Croisades et pèlerinages. Images et langages, Paris, 1987. 
a partir de finales de los ochenta, con ocasión de las lecturas que debí efectuar para escribir mi contribución al primer tomo de la Storia religiosa dell'Italia, aparecido en $1993^{36}$, en el cual Gabriele de Rosa y Tullio Gregory me confiaron la dirección, proporcionándome así una muestra de afecto y amistad. En ínterin, conocí a un sacerdote umbro, don Mario Sensi, que, mientras era párroco de una parroquia de montaña en el nordeste de Foligno, había estudiado como historiador los numerosos santuarios de esa región apoyándose en una abundante documentación de archivo. Sus encuestas y estudios me fueron muy útiles y acabaron por convencerme de la situación paradójica de Italia en este campo: un país donde existía una cantidad increíble de santuarios, grandes y pequeños, la mayor parte de ellos activos, pero que no habían sido objeto de estudio, salvo raras excepciones como el de la Trinidad de Vallepietra, muy querido por los etnólogos pues allí se perpetuaban prácticas religiosas que se podían remontar a la antigüedad.

Así, cuando volví a Roma para mi tercera estancia (1995-2003) me preocupé de poner en marcha un programa de investigación sobre «L'bomme et le sacré dans le pays méditerranéens», cuya realización más destacable fue un «Inventario de los santuarios cristianos de Italia», promovido por la Escuela Francesa de Roma (André Vauchez y Cécile Caby) en colaboración con una quincena de universidades y centros de investigación italianos y animado por Sofia Boesch, Giorgio Gracco, Giorgio Otranto, Gabriele de Rosa, Roberto Rusconi y tantos otros que no puedo citar ahora pero que sin su concurso no hubiera sido posible culminar esta empresa. Este programa de investigación se abrió, en 1997, con un coloquios sobre $\ll$ Lieux de culte, lieux sacrés, sanctuaires» ${ }^{37}$ que nos dio la ocasión establecer las bases metodológicas de nuestra encuesta. No fue fácil llegar a una definición unívoca de lo que entendíamos por la palabra «santuario» en su sentido cristiano, que fue finalmente la siguiente: una iglesia donde se encuentran las reliquias de un santo o de una santa, o las huellas de una aparición (de un ángel o de la Virgen María) o una imagen particularmente prestigiosa, a la que se le atribuyen milagros y que son objeto, al menos una vez al año, de una peregrinación. Entre el año 2000 y el 2004 se hizo un banco de datos digital, accesible en línea, donde se fueron volcando las fichas realizadas por nuestros colaboradores sobre los diversos santuarios de la zona de la que estaban encargados para su estudio.

\footnotetext{
36 Gabriele De Rosa, Tullio Gregory y André VAuCHEZ, Storia dell'Italia religiosa, t. I, L'Antichità e il Medio Evo, a cargo de André Vauchez, Roma-Bari, 1993.

37 André VAUCHEZ (dir.), Lieux sacrés, lieux de culte, sanctuaires, Roma, 2000.
} 
Este no es el lugar para describir todas las etapas de esta empresa que dio lugar a numerosos coloquios de gran interés ${ }^{38} \mathrm{y}$, en el curso de los últimos años, a la publicación de seis volúmenes regionales (Lacio, Umbría, Apulia, Trentino-Alto Adigio, Roma y Romaña) ${ }^{39}$ sobre la quincena que se esperan para cubrir el total del territorio italiano. Uno no puede dejar de asombrarse por el hecho de que, por esos mismos años, un inventario semejante se ha realizado en los Países Bajos ${ }^{40}$, mientras que Dominique Iogna-Prat y Michel Lauwers ponían en marcha un programa de investigaciones sobre la «espacialización» de lo sagrado en la Francia medieval con puntos de interés y objetivos muy semejantes a los nuestros ${ }^{41}$, y que

38 André VAuCHEZ (dir.), Lieux sacrés, lieux de culte, sanctuaires. Approches terminologiques, méthodologiques, historiques et monographiques, Roma, 2000 (Collection de l'École française de Rome, 273); Giorgio GRACCO (ed.), Per una storia dei santuari cristiani d'Italia: approcci regionali, Bologna, 2002 (Annali dell'Istituto storico italo-germanico in Trento. Quaderni, 58); Pierre BoUET, Giorgio OTRANTO y André VAuCHEZ (dirs.), Culte et pélerinages à Saint Michel en Occident. Les trois monts dédiés à l'Archange, Roma, 2003 (Collection de l'École française de Rome, 316); Mario TOSTI (ed.), Santuari cristiani d'Italia. Committenze e fruizione tra medioevo e età moderna, Roma, 2003 (Collection de l'École française de Rome, 317); Giorgio GRACCO, La geografia dei santuari tra medioevo e età moderna, en Annali dell'Istituto storico italo-germanico in Trento, 29 (2003), pp. 211 383; Gaetano DammaCco y Giorgio OTRANTO (eds.), Profili giuridici e storia dei santuari cristiani in Italia, Bari, 2004 (Quaderni di «Vetera Christianorum», 29); AA.VV., Sanctuaires francais et italiens dans le monde contemporain, en Mélanges de l'École française de Rome. Italie et Méditerranée, 117/2 (2005), pp. 456-900; Maria Giuseppina MELONI y Olivetta SCHENA (eds.), Culti, santuari, pellegrinaggi in Sardegna e nella penisola iberica tra Medioevo ed età contemporanea, Genova, 2006; André VAUCHEZ (ed.), I santuari cristiani d'Italia. Bilancio del censimento e proposte interpretative, Roma, 2007 (Collection de l'École française de Rome, 387); Sofia BoEsch GAJANO y Francesco SCORZA BARCELLONA (eds.), Lo spazio del santuario. Un osservatorio per la storia di Roma e del Lazio, Roma, 2008 (Chiese d'Italia, 3); Andrea TilatTi (ed.), Santuari di confine. Una tipologia? Atti del convegno di studi (Gorizia-Nova Gorica, 78 ottobre 2004), Gorizia, 2008; Davide SCOTTO (ed.), Del visibile credere. Pellegrinaggi, santuari, miracoli, reliquie, Firenze, 2011 (Biblioteca della Rivista di storia e letteratura religiosa. Studi, 24) [testi già editi, con il titolo: Pellegrinaggi santuari miracoli nel mondo cristiano tra storia e letteratura, en Rivista di storia e letteratura religiosa, 42 (2006), pp. 414-649].

39 Sofia Boesch Gajano, Maria Teresa Caciorgna, Vincenzo Fiocchi Nicolai y Francesco SCORZa BarCEllona, Santuari d'Italia. Lazio, Roma, 2010; Giorgio Otranto y Immacolata AUlisa (eds.), Santuari d'Italia. Puglia, Roma, 2012; Emanuele CURZEL y Gian Maria VARANINI (eds.), Santuari d'Italia. Trentino - Alto Adige/Süd Tirol, Roma, 2012; Sofia Boesch Gajano, Tommaso Caliò, Francesco Scorza Barcellona y Lucrezia Spera (eds.), Santuari d'Italia. Roma, Roma, 2012; Chiara Coletti, Mario Tosti (eds.), Santuari d'Italia. Umbria, Roma, 2013; Martina CAROLI, Alba Maria OrSELli, Raffaele SAVIGNI (eds.), Santuari d'Italia. Romagna, Roma, 2013.

40 Peter Jan MARgry y Charles CASPERs (coords.), Bedevaartplaatsen in Nederland, 4 vols., Amsterdam-Hilversum, 1997-2004.

41 La spatialisation du sacré dans l'Occident latin médiéval, programa de investigación promovido por el Centro de Estudios Medievales de Auxerre, bajo la dirección de Dominique Iogna-Prat. 
la «Settimana» de Spoleto del 2002 fue dedicada a estudiar «L'uomo e lo spazio nell'Alto Medioevo» ${ }^{42}$. Lo cual pone de relieve que la idea estaba «en el aire»y que los medievalistas han tomado conciencia de que les faltaba una dimensión a sus estudios. Estoy convencido de que este acercamiento espacial y territorial a los fenómenos religiosos puede ser muy fecundo y permitirá renovar una historiografía que desde hace mucho tiempo se ha concentrado sobre las estructuras eclesiásticas (diócesis, «pievi» y parroquias), como si el hombre medieval hubiera sido totalmente sedentario y no hubiera sentido la necesidad de salir de su pueblo o de su barrio para ir en busca de la curación o de la salvación. En efecto, ya se trate de las cruzadas, de los jubileos romanos o de las peregrinaciones locales, estamos siempre en la misma perspectiva que, como había bien visto Alphonse Dupront, es la de un desplazamiento individual o colectivo que permite al hombre comprometerse en la via salutis.

\section{ENTRE PROFETISMO Y FRANCISCANISMO}

P. Recientemente ba acabado de dirigir la redacción de un volumen sobre la bistoria del profetismo. Su antiguo interés por Francisco y el franciscanismo ha llegado a su madurez más o menos por la misma época. ¿Existe algún nexo entre estas dos temáticas? ¿La atención constante que ba dispensado a los temas de la bistoria de la profecía y de la apocalíptica estaba ligada a los intereses por la espiritualidad de los laicos y por la relación existente entre las masas y la religión?

R. Los años siguientes a mi retorno definitivo a Francia y mi jubilación a finales del 2003, han estado marcados, en lo que concierne a mis trabajos más significativos, bajo el doble signo del profetismo y del franciscanismo. Efectivamente, han sido publicados sucesivamente en 2005 el Liber ostensor quod adesse festinant tempora del franciscano Jean de Roquetaillade (†1366), verdadera antología del profetismo latino de mitad del siglo XIV, editado bajo mi dirección; en 2007, una recopilación de estudios sobre Francisco de Asís y el franciscanismo surgido en Asís; en 2009, mi François d'Assise entre histoire et mémoire, y en 2012, el volumen colectivo sobre Prophètes et prophétisme (Paris 2012), también bajo mi dirección.

En realidad, no se trataban de temas de estudios nuevos para mí y este entrecruzamiento de las dos temáticas es por una parte debido al azar: desde finales

42 Uomo e spazio nell'alto medioevo, Spoleto (Perugia) 2003 (Settimane di Studio del Centro Italiano di Studi sull'alto medioevo, L). 
de los años 80, en efecto, yo había iniciado la edición del Liber ostensor con un valioso equipo de colaboradores sin el cual no hubiera sido posible la publicación, puesto que en seguida se reveló como algo muy difícil. Mí partida para Roma en 1995 y la gran carga de trabajo consecuencia de mi función como director de la Escuela francesa me obligaron a dejar de lado la edición de esta obra, a la cual no me pude dedicar hasta el año 2000. Se trata, pues, del cumplimiento tardío de un proyecto ya antiguo.

En cuanto a Francisco de Asís, era una figura que siempre me había fascinado y a la cual había consagrado uno de mis primeros artículos, en 1968, a las reacciones que sus estigmas provocaron en la cristiandad de los siglos XIII y XIV ${ }^{43}$. Pero, por prudencia, me abstuve de dedicarle un lugar importante en mi libro sobre La sainteté au Moyen Âge, aduciendo que las actas de su proceso de canonización -muy expeditivo- no nos habían llegado, y tomé la decisión de poner el acento en los santos de los siglos XIII y XIV que fueron influidos en diferente medida por el franciscanismo. Efectivamente, enseguida me había dado cuenta de que el problema de las fuentes franciscanas era tan complejo y complicado debido a las interpretaciones y dataciones discordantes que me requeriría mucho tiempo su completo dominio. De hecho, no fue hasta treinta años más tarde, después de haber participado anualmente en los coloquios celebrados en Asís por la Società internazionale di studi francescani y beneficiándome de los trabajos de Raoul Manselli, Giovanni Miccoli, Luigi Pellegrini, Attilio Bartoli Langeli, Roberto Rusconi y Jacques Dalarun, así como de las nuevas ediciones de estas fuentes debidas a Enrico Menestò y Stefano Brufani y otros más, que pude sentirme cómodo en esta jungla para poder aventurarme sin cometer grandes meteduras de pata. Por otro lado, la aparición en mi obra de la temática «profética» junto con un interés particular por Francisco de Asís no es totalmente fortuita. Yo me había interesado tempranamente por la componente profética de la santidad, tan importante en los siglos XIV y XV, y a las revelaciones de las cuales numerosos personajes de esta época decían haberse beneficiado. A partir de los años 80, y en particular en 1988 con ocasión de un coloquio que había organizado en Erice con Agostino Paravicini Bagliani ${ }^{44}$, cuyas actas se publicaron en 1992, yo había llamado la atención sobre la importancia de los «poderes carismáticos e informales» en la cristiandad de finales de la Edad Media, poniendo el acento en particular en

43 André VAUCHEZ, Les stigmates de Saint François et leurs détracteurs dans les derniers siècles du moyen âge, en Mélanges d'archéologie et d'Histoire, 80/2 (1968), pp. 595-625.

44 Agostino ParaVicini Bagliani y André Vauchez (eds.), Poteri carismatici e informali: chiesa e società medioevali, Palermo, 1992. 
las relaciones con los poderes institucionales (papado, realeza) que trataban tanto de sacar provecho como de combatirlo, según las circunstancias. Bajo el término de «poderes informales», engloba los tipos de personajes muy diversos que van desde los ermitaños inspirados y las mujeres visionarias hasta los «predicadores estrella» del siglo XV -un Vicente Ferrer, un Bernardino de Siena o un Savonarola, por ejemplo-, que podían ser caracterizados como personajes carismáticos, en la medida en que la influencia que ejercían sobre los espíritus de sus contemporáneos desbordaba ampliamente la función que ocupaban en la Iglesia o en la sociedad. En esta reflexión sobre el papel del carisma en la historia, era inevitable encontrarse con Francisco de Asís que, en su Testamento, reivindica para sí mismo una revelación divina que le habría indicado la vía que debía seguir y que le ganó la consideración por los Hermanos menores de «el primer profeta de su orden», para retomar una afortunada expresión de Nicole Bériou ${ }^{45}$.

P. Usted ha prestado una atención particular a fean de Roquetaillade. Podría explicarnos las razones de este interés.

R. Un trabajo de seminario conducido en Paris por mis «tesinandos», así como los trabajos de Robert Lerner y los de Colette Beaune, mi colega en Paris XNanterre, sobre el mesianismo real en Francia en los siglos XIV y XV ${ }^{46}$, me acabaron de convencer, si es que hacía falta, de que había un filón en el que todo estaba por hacer, comenzando por la edición de numerosos textos que hasta el momento no habían llamado la atención de los historiadores. Con esta idea, organicé un coloquio celebrado en Chantilly, en 1988, sobre Les textes prophétiques et la prophétie en Occident (publicado en Roma en 1990) ${ }^{47}$, con ocasión del cual elaboramos el status quaestionis de estos temas poniendo el acento sobre un personaje clave de esta corriente profética, el franciscano francés Jean de Roquetaillade. Desde siempre considerado como un «espiritual», era discípulo de Olivi, que había anunciado a partir de 1340 la próxima llegada del Anticristo. Por otra parte, fue el primer milenarista convencido, ya que osó contestar la interpretación de san Agustín, que era la «canónica», según la cual el millenium del cual habla el libro del Apocalipsis designaba simplemente el tiempo de la Iglesia y esta desprovisto de toda significa-

45 Nicole BÉRIOU, François d'Assise premier prophète de son ordre dans les sermons du XIII siècle, en Mélanges de l'École française de Rome, Moyen-Âge, Temps modernes, 102/2 (1990), pp. 535-556.

46 Robert E. LERNER, The Powers of Prophecy. The Cedar of Lebanon Vision from the Mongol Onslaught to the Dawn of the Enlightenment, Berkeley etc., 1983; Colette BEAUNE, La Légende de Jean Tristan fils de saint Louis, en Mélanges de l'École française de Rome, Moyen-Âge, Temps modernes, 98/1 (1986), pp. 143-160.

47 André VAUCHEZ (dir.), Les textes prophétiques et la prophétie en Occident (XII -XVI siècle), Roma, 1990. 
ción histórica precisa. La importancia de este personaje y de su Liber ostensor quod adesse festinant tempora - del cual solo queda un manuscrito llegado tardíamente a la Biblioteca Vaticana- había llamado la atención, en los años 1925-1930, a la gran erudita Jeanne Bignami-Odier, que publicó importantes actualizaciones sobre Roquetaillade y su obra pero sin llegar a hacer una edición crítica de este tratado. Casi ciega, al final de su vida, tuvo la bondad de confiarme sus notas así como la preciosa transcripción que había hecho del manuscrito romano, y así nos pusimos al trabajo. El interés particular que presenta este texto consiste en el hecho de que constituye un verdadero compendio de la literatura profética medieval de la primera mitad del siglo XIV, ya que el hermano Jean no se consideraba como un profeta sino que buscaba más bien en las profecías existentes la confirmación de sus intuiciones fundamentales y de sus predicciones.

Esta edición fue una gran aventura que se prolongó por una veintena de años y que absorbió muchísimas energías; pero me parece que el resultado es importante en la medida en que se trata de un texto fundamental para la historia de la literatura profética medieval que se ha puesto a disposición de los investigadores con unas introducciones y unos comentarios muy cuidados. En la misma perspectiva, me pareció útil reflexionar, en la larga medida, sobre el tema del profetismo que está presente, bajo formas y grados diversos, en las tres religiones del Libro (judaísmo, cristianismo e islam). Esto me llevó a tomar la iniciativa de una obra colectiva, aparecida en 2012 bajo el título de Prophètes et prophétisme, de la cual escribí la introducción (metodología e historiografía), y la parte dedicada a la edad media occidental ${ }^{48}$. Pero igualmente se encuentran textos de otros autores sobre el profetismo bíblico y en la época moderna y contemporánea, así como capítulos originales sobre el mesianismo profético en América del norte, del Sur y en el África negra. En contraposición, se han dejado de lado las religiones asiáticas que no han conocido este fenómeno en la medida en que no conceden valor positivo al tiempo, ni a la historia y en cambio privilegian la meditación y la búsqueda de la interioridad.

P. Vayamos a Francisco de Asís que ha ocupado sus pensamientos y trabajos desde el 2004 hasta el 2008. ¿Cuál ha sido su postura frente a las grandes tradiciones de estudios franciscanos, franceses y quizás también italianos, tan dinámicas -en el curso de los últimos decenios-y tan atentas a la bistorización de las «fuentes franciscanas»?

R. La obra que publiqué, en el año 2009, ha sido resultado de una profunda reflexión y de una familiaridad de más de cuarenta años con las fuentes y la

48 André Vauchez (dir.), Prophètes et prophétisme, Paris, 2012. 
historiografía franciscanas. Mi punto de partida era escribir un libro que fuera accesible al gran público culto, integrando las adquisiciones y los progresos considerables de la investigación en esta materia, en particular gracias a los historiadores italianos. En la introducción les rindo un homenaje que no tiene nada de formal, ya todo lo que sé sobre esta materia lo he aprendido de sus trabajos que me han permitido contextualizar las fuentes y situarlas en la perspectiva histórica de su época.

Después de un cierto tiempo, tenía la impresión de un desfase muy grande entre el discurso de los «franciscanistas», que cada vez se hacía más sofisticado e incluso un poco esotérico para el que no pertenecía a esa «cofradía» intelectual, y el discurso de los autores de innumerables biografías y ensayos dedicados al santo de Asís en todas las lenguas posibles, como sí todo este trabajo científico no existiera o no hubiera aportado ninguna novedad, lo cual no era cierto. Esta elección ha complicado mi tarea y explica, sin dudas, que haya tardado más de tres años en redactar el libro, teniendo en cuenta que había recopilado tanta documentación sobre el tema que en muchas ocasiones tuve la impresión de que no llegaría a dominarla... No me toca a mí juzgar sobre el resultado de mis esfuerzos, pero el éxito que ha conocido esta obra, rápidamente traducida al italiano (de un modo excelente, por cierto, por Grado Merlo), en inglés (muy bien también por mi antiguo «tesinando» y excelente franciscanista, Michael Cusato, OFM) y en portugués $^{49}$, me llevan a pensar que como mínimo había salido en el momento justo.

Algunos se han sorprendido de que haya omitido el «san» en el título del libro, pero lo hice a conciencia para evitar dar la impresión de que se trataba de una más de las múltiples biografías que parecen réplicas y están más preocupadas de edificar al lector que de informarle sobre el «poverello» de Asís. Como nadie me puede acusar de no estar interesado en la santidad, prefería intentar mostrar como la experiencia religiosa de Francisco, que ha hecho de él una de las grandes figuras espirituales de la humanidad, se injertaba en una personalidad histórica bien determinada, actuando en una sociedad concreta, y que ha respondido plenamente a la idea de santidad que tenían sus contemporáneos.

P. Como bizo hace unos años su amigo, Jacques Le Goff, con san Luis, usted también escogió el género biográfico, en su sentido amplio, no convencional y claramente como medio para poner en evidencia sus tesis: en efecto, la parte consagrada a la reconstrucción

49 ID., Franceso d'Assisi. Tra storia e memoria, Torino, 2010 (trad. G.G. Merlo); Francis of Assisi: The Life and Afterlife of a Medieval Saint, New Haven, 2012 (trad. M. Cusato); Franciso de Assis. Entre bistória e memoria, Lisboa, 2013 (trad. J. D. Antunes, N. Lopes). 
biográfica no termina con la muerte del personaje. ¿Por qué escogió, a propósito de Francisco de Asís, el género biográfico?

R. La mayor novedad de mi propuesta consiste, creo, en el hecho de que no me he contentado con escribir una biografía en el sentido tradicional del término -del nacimiento a la muerte del personaje- sino que he prestado al menos la misma atención a su «Nachleben» estudiando la imagen de Francisco y sus mutaciones desde el siglo XIII hasta nuestros días. Con este planteamiento, he tomado algunas distancias respecto a Saint Louis de mi maestro y amigo Jacques Le Goff. Él, en su libro magistral sobre Luis IX, solo ha tenido en consideración las fuentes contemporáneas del santo rey francés y no se ha interesado en la historiografía, muy abundante, que se ha desarrollado alrededor de su héroe a lo largo de los siglos siguientes y a las imágenes que de él se han transmitido.

P. En su libro consagrado a Francisco de Asís, justifica el espacio importante consagrado a las imágenes afirmando que todo lo que ba sido producido en tanto que proceso bistórico de interpretación y contestación concierne también al personaje Francisco: «Es posible que boy día podamos comprender mejor a Francisco que sus contemporáneos». Usted define a Francisco como un personaje no acabado afirmando que «su figura se actualiza». ¿Por qué estas afirmaciones, estas «concesiones» de parte de quien, en La sainteté en Occident aux derniers siècles du Moyen Âge, babía severamente llamado a la contextualización histórica de las fuentes hagiográficas?

R. Pienso que, en el caso de Francisco, no es menos interesante e importante saber qué idea se han podido hacer de él en la época de la Reforma protestante o del Romanticismo que la escrita por Thomas de Celano o Bonaventura de Bagnoregio. Porque el inicio no lo decide todo y la verdad no es separable de su transmisión. Así, el historiador debe tener en cuenta los juicios, incluso los malévolos o erróneos, que la posteridad nos ha dejado. Ciertamente, estas opiniones tardías, nos muestran más sobre aquellos que las expresan que sobre el personaje objeto de esos juicios, pero lo mismo podría decirse a propósito de las fuentes, incluso contemporáneas de los acontecimientos o de las personalidades de las que nos hablan. Ya no creemos que Francisco haya sido el precursor del humanismo y del renacimiento o un nuevo Orfeo, pero el sólo hecho de que esa opiniones hayan sido formuladas en el siglo XIX por autores serios pone en evidencia algunos rasgos del personaje. Incluso sin han sido mal interpretados o exagerados, tienen sin lugar a dudas un anclaje en la realidad, o al menos en lo que las fuentes medievales nos dicen de él y a este título, merecen retener nuestra atención. El historiador no ha recibido luces sobrenaturales que le permiten afirmar que conoce al «verdadero san Francisco»; pero, si hace correctamente su trabajo estableciendo una jerarquía entre sus fuentes según su fecha y su fiabilidad, es con 
el fin de señalar que tal o tal lectura de ese personaje es inexacta o francamente aberrante, y a su vez para proponer la suya justificándola.

Uno de los problemas más delicados que encontramos en la biografía de Francisco de Asís es la dificultad para comprender como su espíritu novador y su inspiración plenamente evangélica se puede conciliar con su sumisión a la Iglesia de la que no se puede dudar, incluso sabiendo que fue muy dolorosa en algunos momentos de su vida. Paul Sabatier, cuyo mérito es inmenso pues dio a conocer a Francisco al mundo entero a través de su biografía de 1893-1894, resolvió el problema, como buen protestante liberal que era, oponiendo el evangelismo del Poverello a la voluntad de poder de la Iglesia romana encarnada por el cardenal Hugolino, futuro papa Gregorio IX, y al «realismo» acomodado del hermano Elia, al cual Thomas de Celano le había hecho portavoz. Esto le llevó a imaginar que el Speculum perfectionis -que data de 1317- correspondía a un texto de una Vida censurada por la jerarquía eclesiástica, de la cual el hermano León, fiel secretario y compañero de Francisco, habría sido el autor o el inspirador después de la muerte del Poverello.

Hoy día no queda nada de esta construcción azarosa, pero la idea de que Francisco haya sido fiel devoto a la Iglesia no es admitida por tantos en nuestros días, ya que prevalece la idea de que la institución, por su naturaleza misma, no se puede abrir a los requerimientos del evangelio, a menos que sea para neutralizarlos. $\mathrm{O}$ que se trata de un anacronismo evidente pues, para retomar una respuesta de Juana de Arco a sus jueces -que Francisco habría suscrito- para los cristianos de la Edad Media «el papa y la Iglesia son un todo». Se puede ir más lejos y sostener que Francisco es un producto de la Reforma gregoriana: ¿no es cierto que ha escrito al futuro papa Gregorio IX calificándolo de manera premonitoria como «episcopus totius mundi» (I Cel., 100), fórmula que en la época era de todo menos inocente? Aún respetando las prerrogativas de obispos y del clero secular, el santo de Asís acude a la plenitudo potestatis papale, consciente de que la supervivencia y difusión de su orden dependían de la buena voluntad de la Santa Sede y su respaldo, lo cual permitiría al ordo fratrum minorum conocer una difusión extremadamente rápida en toda la cristiandad. El peor enemigo del historiador es el anacronismo: historiar el debate en torno a Francisco de Asís consiste en primer lugar en levantar acta de nociones que hoy en día parecen irreconciliables y que entonces no eran necesariamente antagonistas.

De manera general, por razones bien comprensibles que se refieren al peso de la Iglesia en la vida de su país y a los lazos complejos que entretejía con el mundo político y económico, los historiadores italianos -con la notable excepción de Cinzio Violante- han tendido por mucho tiempo a juzgar a la Iglesia negativa- 
mente, como si por su propia esencia estuviera destinada a jugar un papel negativo en el dominio de la vida religiosa. Pero esta visión pesimista, perfectamente justificada para algunas épocas, no lo es necesariamente para todas: cualesquiera que hayan sido sus motivaciones, Inocente III tuvo la valentía de canonizar en 1199 a un santo laico, no noble -y además artesano y mercader- en la persona de san Homebon, y su sucesor Honorio III supo reconocer y acoger dentro de la Iglesia el carisma de Francisco. Más que la oposición sistemática entre las dos nociones postulada por Max Weber, creo que el carisma y la institución son los dos polos de la vida de la Iglesia: la institución sin carisma se convierte en una maquina administrativa y judiciaria sin alma; el carisma sin la institución se arriesga a no sobrevivir a su poseedor o a perderse en la marginalidad. De una tensión sin ruptura entre estos dos polos es donde puede nacer, en ciertos momentos de su historia, un nuevo dinamismo y los movimientos de reforma en el seno de la Iglesia. Ciertamente, el carisma nunca es asumido tal cual en la institución y he insistido mucho al final de mi libro sobre el hecho de que buena parte del mensaje de Francisco de Asís no ha encontrado eco en su tiempo y ha sido rápidamente olvidado, a riesgo de que más tarde pudiera resurgir. Pero no es menos cierto que lo que la cristiandad medieval ha retenido de él ha sido suficiente para insuflar un espíritu nuevo y para favorecer la difusión en su seno de ciertos fermentos evangélicos.

\section{DE LAS «IMÁGENES VIVIENTES» A LA HISTORIA DE LA SANTIDAD FEMENINA}

P. En el curso del coloquio que se ha desarrollado en Paris en el año 2009, en vuestro honor, usted ha afirmado que «creía mucho» en la iconografía. Algunos de sus estudios ${ }^{50}$ así lo ponen de relieve y su libro sobre Francisco de Asís lo confirma. Además, algunos de sus discípulos son especialistas en estudios iconográficos (Daniel Russo, Dominique Rigaux). En los orígenes de sus investigaciones hagiográficas, ¿cuál era el problema de las relaciones entre las imágenes y el culto de los santos? ¿De qué manera, esta sensibilidad ha sido influida por la evolución de conjunto de la sociedad occidental en los últimos decenios y por la atención centrada, en general, por las ciencias humanas sobre el hecho icónico?

R. Alguno me ha atribuido el mérito de haber sensibilizado a los medievalistas sobre la importancia de las imágenes como fuentes, tan válidas e importantes

50 André VAUCHEZ y Joanna CANNON, Margherita of Cortona and the Lorenzetti. Sienese Art and the Cult of a Holy Woman in Medieval Tuscany, University Park (Pa), 1998; Margherita da Cortona e i Lorenzetti, Roma, 2000 (traducción de A. D’Alessandro, G. Freni, F. Iozzelli). 
como los documentos o las crónicas. Esto es demasiado elogioso, porque este descubrimiento de las importancia de la iconografía, sobre todo para una época en que la mayoría de la población no sabía ni leer ni escribir, es un fenómeno de toda una generación. Debo reconocer, honestamente, que las imágenes que he publicado en gran número en mi libro sobre la La sainteté en Occident son simples ilustraciones que tienen como objetivo completar en mi discurso lo que pueda haber de abstracto o árido.

Pero sí que es cierto que he adquirí desde los comienzos una cierta sensibilidad sobre el papel de la imagen, que explica, sin lugar a dudas, que mis dos primeros alumnos -que después han llegado a maestros-, Dominique Rigaux y Daniel Russo, hayan sido especialistas de la iconografía y que yo haya podido escribir un libro con una historiadora del arte, Joanna Cannon, sobre santa Margarita de Cortona, cuyo punto de partida era una serie de dibujos del siglo XVII donde se encontraban copiados los frescos que ornamentaban la iglesia dedicada a la santa encima de Cortona, antes de su destrucción. Pero es a ella a quien hay que otorgar el mérito de haber estudiado este ciclo pictórico en todos sus detalles demostrando que se trataba de una obra de Lorenzetti, mientras que yo me ocupaba de rescatar la historia del culto de esta santa mujer y del papel que tuvo en la religión cívica de su población. Por el contrario, me puedo considerar como perteneciente a una cohorte de historiadores medievales que -desde Jean Claude Schmitt a Jean-Marie Sansterre- han llamado la atención sobre el papel de las «imágenes vivientes» (las vírgenes que lloran, los crucifijos que sangran, etc.) como nexo de las sacralidad y sustitutos de las reliquias en el cuadro del culto a los santos. En este campo, he aprendido mucho de Chiara Frugoni cuyo bello libro sobre L'invenzione delle stimmate ${ }^{51}$ me sedujo no tanto por la tesis que desarrolla sobre la realidad (o no) de los estigmas de Francisco de Asís que por el uso que hace de los frescos y de las pinturas medievales como fuentes, poniéndolos al mismo nivel que los textos, que conocía igual de bien, y por el dominio con el cual relaciona los dos tipos de documentos.

Por mi parte, he intentado mostrar, siguiendo a Rosalind Brooke ${ }^{52}$, que las escenas de la vida de san Francisco pintadas por Giotto, en la basílica superior de Asís, respondían a una elección, sin duda impuesta por sus mandantes, que llevaba a excluir ciertos episodios o aspectos mayores de su existencia terrena y ponían

51 Chiara Frugoni, Francesco e l'invenzione delle stimmate. Una storia per parole e immagini fino a Bonaventura e Giotto, Torino, 1993.

52 Rosalind Brooke, The Image of St. Francis: Responses to Sainthood in the Thirteenth Century, Cambridge-New York, 2006. 
el acento sobre otros, como sus relaciones con el papado y sus milagros más extraordinarios, lo que traicionaba el sentido originario del mensaje franciscano. En general, creo que el recurso a las fuentes iconográficas puede renovar y enriquecer nuestra manera de «hacer la historia», con la condición de que un corpus de imágenes lo más exhaustivo posible sea elaborado y puesto en obra desde una perspectiva científica que no sea la de la historia del arte tradicional. Con las posibilidades casi ilimitadas que ofrece la informática, esto debería hacerse sin excesiva dificultad, pero constato con pena que el progreso en este vía es aún limitado y que, con mucha frecuencia, hoy día, la constitución de bases de datos acapara de tal manera a los investigadores que no tiene ya fuerzas o capacidad para ponerla en pie...

P. Además de su amplia dedicación a los estudios franciscanos, un tema que ba cultivado con continuidad y predilección ha sido el de la santidad femenina y las experiencias religiosas femeninas, tema puesto particularmente de relieve en sus recopilaciones ensayísticas (tituladas Saints, prophètes et visionnaires: le pouvoir surnaturel au Moyen Âge, e igualmente Expériences religieuses au Moyen Âge, en la cual una sección particular está dedicada $a$ «La sainteté au féminin») $)^{53}$. ¿Puede profundizar en este aspecto de sus estudios que nos conducen a temas que se han consolidado definitivamente en el seno de la investigación bistórica?

R. Por lo que respecta a mi contribución personal a la historia de la santidad femenina, esta debe ponerse en relación con la «Gender History», una corriente de estudios consagrados a la historia de las mujeres, nacido en Norteamérica y que tuvo su impacto en Europa a partir de los años 80. Muy tempranamente he sido sensibilizado con estas cuestiones, gracias a poder seguir durante años el seminario de Georges Duby en el Collège de France que estaba dedicado al papel de las mujeres en la sociedad medieval, y del cual recuerdo haber hecho una exposición sobre la Vida de María de Oignies (†1213) por Jacques Vitry. Las investigaciones que había llevado a cabo en vista de mi tesis sobre La sainteté en Occident me habían permitido tomar consciencia de la aparición, a partir del siglo XIII, de nuevos modelos de santidad propuestos a las mujeres laicas. Esto modelos tenían su eje por un lado en la dimensión caritativa de la vida cristiana, como en el caso de santa Isabel de Hungría, y por otro lado en el sentido espiritual con figuras como Clara de Asís, Clara de Montefalco y Margarita de Cortona que están en

53 Las ediciones Marietti han confiado a André Vauchez el prefacio de la obra de Benedicto XVI, Donne nel Medioevo. Il genio femminile nella storia del popolo di Dio, Genova, 2011. En el prólogo, Vauchez subraya a «su ilustre colega» (p. 10) que en la Edad Media algunas mujeres habían franqueado las barreras ligadas a la distinción y a la repartición tradicional de los papeles entre los hombres y las mujeres. 
el origen de aquello que se ha dado en llamar «invasión mística», tomando una expresión utilizada por el abbé Brémond para designar la subida al poder del misticismo, sobre todo femenino, en la Francia del siglo XVII.

En los inicios de los ochenta, he hecho una gira de conferencia por los Estados Unidos y he sido invitado a hablar de mis trabajos sobre la santidad femenina en la universidad de Columbia, en Nueva York. Esperaba que este seminario reuniera a un pequeño número de especialistas pero, para mi sorpresa, he tenido que hablar en una gran sala donde se agolpaban centenares de personas, la mayoría mujeres. Mi discurso tuvo la gracia de caer bien y desde ese momento fui considerado como un representante de la «Gender History»... Lo cuál era demasiado honor para mí, incluso si considero que esta problemática ha aportado una renovación benéfica a los estudios históricos. Sea lo que sea, he tratado de mostrar en mis diversos estudios que la mujer ha sido a partir del siglo XIII el objeto de todos los cuidados por parte de las esferas dirigentes de la Iglesia que habían comprendido que si perdían el apoyo del sexo débil, que en ciertas regiones se mostraba sensible al proselitismo de los herejes, las consecuencias serían graves. En este contexto de competencia, los clérigos llegaron hasta el punto de poner en duda la jerarquía tradicional de los estados de perfección y admitieron, a partir de los años 1230-1250, que el nexo entre santidad y virginidad no tenía nada de definitivo y que era posible a una mujer casada santificarse sin renunciar a su estado. En el siglo XIV, se aprecia igualmente como la relación entre las mujeres santas y sus confesores o directores de conciencia se invierte, como ilustran claramente los ejemplos de santa Brígida y santa Catalina de Siena. Al lado de estos grandes nombres, me he interesado por figuras menos claras, pero no menos interesantes, como la de B. Panacea, una piadosa pastora de la Valsesia asesinada por su madrastra a inicios del siglo XIV, cuya historia solo es conocida por los frescos que aún subsisten en algunas iglesias de esa región y que fui a estudiar in situ. Uno se da cuenta de la gran distancia existente entre el ideal de santidad propuesto por los clérigos a las mujeres de un medio social urbano y aristocrático, y por otra parte una concepción popular pegada a un modelo tradicional de mártir que identifica simplemente la santidad con la inocencia ultrajada.

\section{ROMA ENTRE HISTORIA Y MITO}

P. Aparte de haber vivido una buena parte de vuestra vida en Roma también ha consagrado numerosas publicaciones a la bistoria de esta ciudad, comenzando por Rome l'idée et le mythe, con codirección con A. Giardina; y después Roma medievale para las ediciones de Laterza. ¿Qué representa Roma para André Vauchez? 
R. Durante mi última estancia romana, un editor parisino me pidió que escribiera un libro sobre Roma y, después de haber asegurado la participación de un eminente erudito de la antigüedad en la persona de Andrea Giardina, di mi consentimiento a pesar de la novedad que suponía el encargo. Pero mi experiencia de la Ciudad eterna, que empezaba a ser larga, y el interés que tenía por la Roma medieval, mejor conocida gracias a los progresos recientes de la arqueología y de la apertura del museo de la Crypta Balbi, me permitieron, creo, comprometerme sin asumir demasiados riesgos en este proyecto donde otros más competentes me habían precedido, desde Arturo Graf hasta mi querido colega Arnold Esch. En este libro, que apareció primero en francés ${ }^{54}$, pero que tuvo mucho éxito en su edición italiana ${ }^{55}$, me encargué de la época medieval y la «Early Modern», mientras que Giardina se ocupaba del período que va del Siglo de las Luces hasta nuestros días. Fue un verdadero placer escribir este libro porque fue un motivo para estudiar de cerca los mitos sobre Roma y sus interferencias: la versión cristiana retomada y amplificada por el papado a partir de Gregorio VII, la versión imperial que se afirma a partir del siglo IX pero que conoce su versión definitiva en tiempos de Federico Barbaroja de Federico II, y finalmente la versión comunal, ilustrada en el siglo XIV por Cola de Rienzo pero cuyo origen es anterior. De todas estas lecturas, más o menos míticas de Roma y de su historia, es finalmente la de la Iglesia la que se impone en la época del Renacimiento, gracias al papel principal que juega la Roma de los papas a partir de esta época en el plano artístico y cultural, pero a precio de una ruptura de la unidad religiosa de la cristiandad que arruinó por su base el proyecto universalista «romano» del cual se creía portador.

Un poco después, el mismo editor, Giuseppe Laterza, me pidió que dirigiera un volumen sobre la Roma medieval en el marco de una historia de Roma en seis volúmenes. Acepté encantado esta petición halagadora en la medida en que significaba para mí llamar en causa a los mejores especialistas y tener un papel de coordinador super partes. Además, sabiendo que un libro tal no tenía parangón en Francia y que recogía los progresos considerables realizados sobre la historia de Roma en la Edad Media en el curso de los últimos treinta años, me encargué de que fuera traducido y publicado en francés ${ }^{56}$. Conseguí mi propósito a finales del 2010, no sin dificultad pues los editores parisinos dudaban del interés del

54 Andrea GIARDINA y André VAUCHEZ, Rome, l'idée et le mythe: du Moyen Âge à nos jours, Paris, 2000

55 ID., Il mito di Roma da Carlomagno a Mussolini, Roma-Bari, 2001.

56 André VAuCHEZ (ed.), Storia di Roma dall'antichità a oggi. Roma medievale, Roma-Bari, 2001; ID. (dir.), Rome au Moyen Âge, Paris, 2010. 
tema para el público, teniendo en cuenta que los turistas que visitan Roma solo se interesan por las obras maestras del arte que han dejado la Antigüedad, el Renacimiento y el Barroco. Espero haber contribuido con esta publicación a desmontar estos prejuicios y, en todo caso, estoy feliz de haber encontrado el medio de reconocer todo lo que debo a la ciudad de Roma donde he pasado dieciocho años de mi existencia y no los menos importantes.

\section{ENTRE FRANCIA E ITALIA. LA ENSEÑANZA UNIVERSITARIA, LA ORGANIZACIÓN DE LA INVESTIGACIÓN, EL «SISTEMA CULTURAL»}

P. Usted ha entablado un diálogo rico y fecundo con la historiografía medieval italiana, que empezó con su asistencia a las Settimane della Mendola y que se consolidó de manera sustancial durante el período de director de la sección medieval de la Escuela francesa de Roma. El contacto prolongado con una bistoriografía y una religiosidad como la italiana, ¿ ¿ha influido de alguna manera en su manera de concebir la bistoria religiosa?

R. De hecho uno de los aspectos más originales de mi carrera y de mi existencia ha sido que durante cincuenta años no he cesado de moverme entre Francia e Italia, a la cual considero mi segunda patria. Ya he dicho todo lo que debo a la historiografía italiana y no quisiera repetirme. Pero es cierto que las estancias prolongadas y reiteradas en ese país han sido para mí una experiencia fundamental. He encontrado en Roma y en Italia una documentación superabundante y sobre todo un interés por lo medieval sin igual en ningún otro país europeo, donde los medievalistas deben justificarse para consagrar su tiempo a una civilización marcada, a los ojos de sus contemporáneos, por el obscurantismo y la intolerancia. Es cierto que la época medieval ha sido sin lugar a dudas la época más grande de la historia italiana y que las huellas que subsisten son infinitamente más numerosas que las de otras, debido a que no ha conocido ni el shock de la reforma protestante, ni el de la Revolución francesa en su fase más radical. Pero cuando uno trabaja en Italia se admira de la cantidad de personas que sin tener necesariamente títulos académicos, sienten pasión, a nivel local, por la historia y la cultura de la Edad Media. Tuve la fortuna, hace unos años, de formar parte de la comisión encargada de designar el vencedor de las fiestas y de las justas «medievales» de Calendimaggio en Asís. Quedé impactado al constatar que no se trataba de un espectáculo pensado para atraer turistas, sino de una encarnizada lucha entra las dos partes de la ciudad -la «parte di sotto» y la «parte di sopra»- para lograr el reconocimiento de la superioridad de una sobre la otra lo que implicaba una inversión muy grande de tiempo y dinero: 
la calidad de las demostraciones de los dos bandos eran dignas de mención y cada una de ellas había puesto tanto cuidado al intentar revivir el espíritu y el decoro medieval que fue difícil al final decidir cuál era el mejor. Se puede decir lo mismo del Palio de Siena, con sus rivalidades encarnizadas entre las diversas «contrade», y para tantas fiestas locales que son, en primer lugar y sobre todo, un espectáculo que la ciudad se ofrece a sí misma desplegando todos sus recursos humanos y culturales.

P. Usted representa un testimonio de carne y hueso de ese clima de compartición cultural entre los países europeos. Aparte del primer período pasado en Roma, más tarde ha tomado la dirección de la Escuela Francesa de Roma de 1995 al 2003. La manera en que ha dirigido la Escuela se ha inspirado en los mismos principios de su primer período romano. En este sentido, el proyecto de investigación colectivo sobre los santuarios cristianos, que ba reunido al menos a diecinueve universidades italianas en torno a la Escuela, constituye un testimonio claro de esta dirección. ¿Qué balance bace de esta experiencia?

R. Entre Francia e Italia existe evidentemente una gran proximidad que se basa en nuestras comunes orígenes latinos, pero existían también, en los años sesenta, muchas ignorancias mutuas e incomprensiones. Mi situación privilegiada en la Escuela francesa de Roma hizo de mí un «mediador» entre los dos países: desde 1981, organicé con monseñor Maccarrone un coloquio franco-italiano de historia religiosa que se celebraba en Chámbery, en la Saboya, y algunos años más tarde, empecé a acoger en Paris X-Nanterre a los estudiantes que llegaban de La Sapienza dentro del cuadro de programas de intercambio Erasmus. Fue para mí una ocasión de conocer a jóvenes investigadores, algunos de los cuales han hecho carrera en su país y son amigos míos. Además, la colaboración entre la Escuela de Roma y diecinueve universidades y centros de investigación italianos dentro del proyecto de «Censimento dei santuari italiani» me dio la ocasión de profundizar en el conocimiento de la realidad universitaria y humana del país dentro de su diversidad, del Valle de Aosta a la Apulia y a la Sicilia. No solamente he sido siempre bien acogido por los colegas italianos, sino que he encontrado, por su parte, una gran disponibilidad para trabajar con nosotros y con los equipos franceses -como fue el caso de la arqueología medieval- cuando pedimos su colaboración desde la Escuela. Allí han nacido amistades y colaboraciones muy fecundas que nos han permitido superar las diferencias nacionales.

El único reproche que podría hacerle a la historiografía italiana consiste en que no se interesa por lo que ocurre en otros países: numerosos investigadores franceses o alemanes trabajan sobre la Italia medieval, pero solo conozco uno o dos entre mis homólogos italianos que estén interesados en la historia de Fran- 
cia. Este desequilibrio puede explicarse por el hecho de que no exista del lado italiano una estructura semejante a la Escuela francesa de Roma o a los institutos históricos y arqueológicos alemanes en Italia; por otro lado, la documentación archivística es tan abundante en Italia que no hay razón para que los doctorandos busquen fuera lo que tienen en su casa. Esta situación, no obstante, presenta algunos inconvenientes como la regionalización de la investigación y su encerramiento en un provincialismo de vía estrecha.

Las cosas están evolucionando en el buen sentido de la palabra desde hace unos años y puedo comprobar como algunos medievalistas italianos enseñan en las universidades francesas, en particular en la regiones alpinas y en Aviñón. Pero la crisis que atraviesa actualmente el sistema universitario en Europa corre el peligro de frenar esta evolución y de provocar un repliegue sobre los recursos locales. En conjunto y a pesar de las dificultades recientes, Italia sigue siendo un paraíso para los medievalistas en la medida en que la investigación -contrariamente a lo que sucede en Francia- no depende esencialmente del Estado, sino que es sostenida por las colectividades territoriales (regiones, provincias), las municipalidades y por ciertas instituciones eclesiásticas. Ya que la Iglesia, bajo sus diversas manifestaciones (diócesis, pero sobre todo órdenes religiosas), no ha renunciado a jugar un papel sobre el plano cultural organizando y favoreciendo les encuentros científicos y las publicaciones de calidad en el dominio religioso de la Edad Media. Aunque es cierto que el financiamiento público es cada vez más raro, como sucede ahora, otras instituciones pueden tomar el relevo, lo cual concede al sistema una cierta capacidad de maniobra.

\section{PROBLEMAS Y PERSPECTIVAS DE LA INVESTIGACIÓN HISTÓRICA}

P. Esta entrevista concluye con una cuestión relativa a las políticas actuales sobre la investigación, tema muy debatido en Italia, en particular por lo que se refiere a la evaluación de los historiadores que pertenecen a la Universidad. A este respecto, ¿Cuál es la situación en Francia y cuál es su juicio personal sobre la coyuntura actual de la investigación bistórica?

R. No puedo disimular mi inquietud ante la tendencia, que no cesa de acentuarse en los medievalistas europeos, a publicar solo en el marco de los coloquios que cada vez son más numerosos, mientras que las obras personales, que son las que dejan huella, son cada vez más escasas. Está claro que este fenómeno es debido en gran medida a la situación de los autores, que hoy día se encuentras sobrecargados de tareas pedagógicas y administrativas en sus universidades y no 
tienen apenas tiempo para redactar libros, ejercicio que exige una dedicación prolongada. Pero me temo que es una deriva peligrosa porque lo más importante en la obra de un historiador son sus libros: si no hubiera leído en mi juventud Les intellectuels au Moyen Âge de Jacques Le Goff y Le Mâconnais de Georges Duby, sin duda no habría llegado a ser medievalista...

$\mathrm{Si}$ he podido influir un poco en la historiografía de finales del siglo XX en mi campo de estudio, ha sido porque he dedicado doce años de mi existencia a preparar y redactar La sainteté en Occident. El trabajo colectivo está perfectamente justificado cuando se trata de una edición de textos: hubiera sido del todo imposible concluir el Liber ostensor de Jean de Roquetaillade si no hubiera podido contar con el apoyo -y en algunos momentos el empuje- de mis colaboradores; o la publicación del Dictionnaire encyclopédique du Moyen Âge, sin la ayuda de Catherine Vincent y la colaboración de una multitud de autores. Lo mismo podría decir para la constitución del corpus documental informatizado, como los tres cederrones que contienen el conjunto de las cartas editadas y de las súplicas de los papas de Aviñón, cuya realización he supervisado, junto con otros, entre 1972 y 2003. Pero precisamente me inquieta ver que en la actualidad la realización de estos instrumentos de trabajo, por otro lado muy útiles, absorben lo esencial de las energías de los jóvenes investigadores, sin que se produzca, por el momento, un enriquecimiento substancial de la producción histórica propiamente dicha. Espero que se trate solamente de una fase de transición y que los esfuerzos humanos y financieros desplegados para la puesta en línea de la documentación y de los documentos de trabajo indispensables para los medievalistas no les hagan perder de vista el carácter fundamentalmente individual de lo que Marc Bloch llama «el oficio del historiador».

Tengo, también, otra inquietud: en Francia, hoy en día -pero creo que se trata de un fenómeno que se verifica a escala europea-, los organismos encargados de promover la investigación tienden cada vez más a establecer prioridades científicas, definidas por misteriosos comités que reflejan las ideas de su tiempo, y que solo subvencionan los candidatos que presentan proyectos que cuadren con los temas de su gusto. En Francia, el CNRS recluta, esencialmente, los nuevos investigadores entre los de «postes fléchés» que corresponden a objetivos precisos que las instancias de este organismo consideran como prioritarias, lo que no deja ninguna opción de contratar a los que trabajan en otros campos o direcciones. A nivel europeo, los organismos como la Fundación europea de la ciencia hacen lo mismo reservando sus créditos a aquellos que proponen investigaciones sobre temas «políticamente correctos», que no son necesariamente los más interesantes o los más válidos para el período histórico en cuestión. 
Existe un gran peligro para la investigación porque la selección, que se ha de efectuar necesariamente, no se funda en la calidad científica intrínseca de los proyectos, sino en su conformidad con una cierta idea -habitualmente no formulada- de lo que es importante en Historia y de lo que no lo es. En consecuencia, amplios sectores de esta disciplina, empezando por la historia religiosa y de las mentalidades, quedan en barbecho y la libertad de elección de los temas de investigación por los investigadores en ciencias humanas corre el peligro de no ser más que una ficción. Lo que será aún más injusto y peligroso es que dentro de esta joven generación, muchos historiadores de gran talento no podrán ver realizada su vocación, aun cuando sus proyectos sean, a menudo, originales y novedosos. 
